\title{
Mudskipper as an Indicator Species for Lead, Cadmium and Cuprum Heavy Metal Pollution in the Mangrove, Ambon, Indonesia
}

\author{
Kristin Sangur ${ }^{1}$, Fredy Leiwakabessy ${ }^{1}$, Hasan Tuaputty ${ }^{1}$, \\ Laura Vintan Tuwankotta ${ }^{2}$, Sisilya Vionetha Samloy ${ }^{2}$, Costantina Ratila ${ }^{2}$, \\ Olivia Basye Salakory ${ }^{2}$, Chimberly Matulessy ${ }^{2}$, Dominggus Rumahlatu ${ }^{1 *}$
}

\author{
1 Study Program of Biology Education, Faculty of Teacher Training and Education, Pattimura University, Jl. Ir. M. \\ Putuhena, Ambon 97233, Indonesia \\ 2 Study Program of Biology Education, Graduate Students, Pattimura University, J. Ir. M. Putuhena, Ambon \\ 97233, Indonesia \\ * Corresponding author's e-mail: dominggus_amq@yahoo.co.id
}

\begin{abstract}
The heavy metal pollution in seawater and sediment can damage mangrove ecosystems and accumulate in mudskipper (Periophthalmus spp.) that lives in mangrove forests. The accumulation of heavy metal in mudskipper can affect the structure of its gill tissue, liver, and muscles. This research aims at (1) analyzing the levels of lead, cadmium and cuprum heavy metals in mudskipper, sediment, and seawater and (2) analyzing the damage to the gill, liver, and muscle tissue of mudskipper due to the exposure to heavy metals. The mudskipper samples were collected from the mangrove forests of Poka, Waai, and Rutong from May to June in 2019. The heavy metal analysis was conducted using the AAS method, while the gill, liver and muscle tissue staining was carried out with the HE (Hematoxylin Eosin) staining method with 40x magnification. The data were analyzed using descriptive analysis and correlational analysis. The results of the analysis showed that based on the mangrove locations, the order of $\mathrm{Pb}$ and $\mathrm{Cu}$ accumulation in mudskipper was Rutong $>$ Poka $>$ Waai; while the order of the Cd accumulation was Rutong $>$ Waai $>$ Poka. The changes in the gill tissue structure due to the exposure to heavy metals were in the form of teleangiectasia, secondary lamellar edema, hyperplasia, epithelial desquamation, clubbing, and primary lamellar edema. The changes in the liver tissue structure due to the exposure to heavy metals involved hemorrhage and fat degeneration. The changes in the muscle tissue structure due to the exposure to heavy metals include changes in muscle fibers, edema, and necrosis. The highest accumulation of $\mathrm{Pb}$ and $\mathrm{Cd}$ was found in gills and muscles from seawater, while low level of heavy metal $\mathrm{Cu}$ was found in the liver.
\end{abstract}

Keywords: heavy metals, lead, cadmium, cuprum; mangrove; mudskipper

\section{INTRODUCTION}

The heavy metal pollution in marine environment is caused by industrial and mining waste (Gümgüm et al., 1994), geographical, industrial, agricultural, pharmaceutical, domestic, and atmospheric wastes (He et al., 2005; Tchounwou et al., 2012). According to Şireli et al. (2006) and WHO (2008), heavy metals such as lead, cadmium and cuprum are toxic, and are mostly found in marine environments. In addition, the heavy metals in marine environments cannot be degraded, and can accumulate in organisms through industrial, atmosphere, soil, water cycles and food chain processes (Ziyaadini et al., 2017; Rodríguez et al., 2015; Monsefrad et al., 2012; Naghshbandi et al., 2007).

A lot of research has been conducted on the accumulation and distribution of heavy metals in marine environments and various biota, for example, the research on the heavy metal contamination in water and sediment conducted by (Bhuyan et al., 2017; Varol and Sen, 2012), and the research on heavy metal concentrations in Oysters (Crassostrea $\mathrm{sp}$ ) in Setiu Wetlands, Terengganu (Shaari et al., 2016). Bioaccumulation of heavy metals in water 
and bodies of organisms depends on the ability of the organisms to accumulate metals and the heavy metal concentration in sediment, as well as the eating habits of these organisms (Eneji et al., 2011). The metal contamination in marine waters and sediments remains a global threat to biodiversity and humans (Edokpayi et al., 2015).

Heavy metals discharged by ship activity and gas-producing plants have contaminated marine environments. Therefore, monitoring on the water quality should be carried out to reduce health problems and to maintain the stability of aquatic ecosystems (Khan et al., 2018). Besides, Bhuyan et al. (2017) explained that the level of contamination and seasonal variations had an effect on the high levels of heavy metals in waters and sediments. Sediment is a source of heavy metal contamination in waters (Gu et al., 2016; Gu and Lin, 2016; Rosales-Hoz et al., 2003). Heavy metals can be absorbed and precipitated with sediment, along with the formation of heavy metalsediment complexes. This can occur due to the physical and chemical properties of sediments (Pekey, 2006; Okafor and Opuene, 2007; Bibak et al., 2018). Bazzi (2014) explains that the threat of heavy metals in coastal waters can be analyzed through water analysis, sediment analysis, and marine organism analysis.

On the other hand, the use of organisms as pollution indicator species to monitor heavy metals in waters has become the current research trend. Rahmanpour et al. (2016) used the Asian stinging catfish or fossil cat (Heteropnestis fossilis) and crab (Parasesarma persicum) as pollution bioindicator species to monitor the $\mathrm{Hg}$, As, $\mathrm{Cd}, \mathrm{Pb}$ and $\mathrm{Cu}$ heavy metals in the Arvand River. Rumahlatu and Huliselan (2016) used Apogon beauforti as a bioindicator species to monitor the $\mathrm{Hg}$ pollution in Ambon Island waters. Vaidya (2017) reported that there were 19 species of zooplankton as pollution bioindicators in Nagpokhari Kathmandu. Moreover, Wickramasinghe et al. (2017) reported that the accumulation of the $\mathrm{Cu}, \mathrm{Cd}$ and $\mathrm{Pb}$ heavy metals had an effect on the pigmentation and productivity of the Fucus vesiculosus and Ulva lactuca algae, and both types of algae can be used as bioindicators to monitor the metal pollution in coastal waters. Mbeh et al. (2019) reported that the level of heavy metal $\mathrm{Cu}$ in fish was higher than that in crustacean species.

One of the aquatic organisms that can be used as a pollution bioindicator in mangrove forests is the mudskipper fish (Periophthalmus spp.).
This is because mud, one type of mangrove forest substrate, accumulates a lot of nutrients and minerals, including heavy metal pollutants. Consequently, the bodies of the mudskipper fish that live immersed in mud can also accumulate heavy metals. The mudskipper fish, which lives immersed in mud and jumps on the mud, is very tolerant to inorganic and organic pollutants. Therefore, mudskipper fish potentially accumulates the heavy metals disposed from industry, agriculture, domestic and transportation activities. Thus, this fish is very suitable for a marine bioindicator species (Polgar et al., 2010; Dabruzzi et al., 2011; Ansari et al., 2014). According to Bu-Olayan and Thomas (2008), the Periophthalmus waltoni mudskipper is prey for predators in mangrove ecosystems, lives in mud during both high tides and low tides, and is capable of accumulating the $\mathrm{Zn}, \mathrm{Cu}, \mathrm{Cd}$ and $\mathrm{Fe}$ heavy metals. Therefore, it can be used as a marine bioindicator species.

Mudskipper is abundantly found in the mangrove ecosystems of Poka, Waai and Rutong villages. The mangrove ecosystem of the Poka village represents the deep Ambon bay area. Meanwhile, the mangrove ecosystems of the Waai and Rutong villages represent the areas facing the open sea. The main sources of pollution in the mangrove forest in the Rutong village are household waste in the form of inorganic and organic waste, wastewater from laundry and car wash, and fishing activities in the form of fishing boats tied to mangrove trunks. Meanwhile, the main sources of pollution in the mangrove forest in the Poka village are organic and non-organic household waste, animal waste, and shipyard industrial activities. The main sources of pollution of the mangrove forest in the Waai village are household waste in the form of inorganic and organic waste, as well as fishing activities in the form of fishing boats tied to mangrove trunks. The research by Souisa (2017) and Male et al. (2017) also revealed that the accumulation of the $\mathrm{Pb}$ and $\mathrm{Cd}$ heavy metals was found in seawater and the sediments of the deep Ambon bay due to the community activities, residential areas, traditional transportation activities in the form of boats or speedboats, as well as the presence of PLTD (Diesel Power Electricity Generator) and shipyards. The source of $\mathrm{Pb}$ pollution comes from human activities which include burning fossil fuels and mining activity. Moreover, lead is also used in industrial activities, such as agriculture, paint making, battery manufacturing, 
ammunition, pipes, and devices to avoid X-rays, ship traffic, and lead-zinc smelting (Mulligan et al., 2001; Tchounwou et al., 2012). Gaetke et al. (2014) explained that the sources of the $\mathrm{Cu}$ pollution include water pipes, cooking utensils, and fungicides for swimming pools. Hasan et al. (2016) argued that industrial activities which included gas production, shipyard, port activities, urban waste, and metallurgical activities were the sources of the $\mathrm{Cd}$ pollution in the Bengal Bay. Therefore, the heavy metal accumulation analysis in the mangrove ecosystems of Waai and Rutong villages is essential.

According to Tanjung et al. (2019), aquatic organisms will absorb the heavy metals that accumulate in waters, but these heavy metals become toxic to the bodies of the aquatic organisms. The same thing will also occur to the body of mudskipper. The toxicity of the absorbed heavy metals can physiologically, morphologically, and genetically disrupt the homeostasis of mudskippers. According to the research results by Moslen and Miebaka (2016), this can happen because of the ability of mudskippers to accumulate and increase the levels of $\mathrm{Cr}, \mathrm{Ni}, \mathrm{Pb}, \mathrm{Ag}$ and $\mathrm{Cd}$ heavy metals in the tissue without physical stress and season influences. In fact, the accumulation of $\mathrm{Pb}, \mathrm{Cd}$, and $\mathrm{Cu}$ heavy metals in the body of mudskippers can cause the structure of the fish tissue to be anomalous. The research results by Dange and Manoj (2015) also reported that the $\mathrm{Cu}, \mathrm{Zn}$ and Ni heavy metals were found to accumulate in the digestive tract of mudskipper fish. Renieri et al. (2014) also reported that higher levels of $\mathrm{Cd}, \mathrm{Pb}$, and $\mathrm{Hg}$ heavy metals were accumulated in the liver and muscles, compared to fish gonads. This is affected with seasons and the age of the fish. Moreover, Thakur and Mhatre (2015) confirmed that the levels of heavy metal accumulation in fish depend on the species, age, and gender of the fish. The research conducted by El-Moselhy et al. (2014); Reyahi-Khoram et al. (2016) and Arantes et al. (2016) reported that the highest concentrations of heavy metals $(\mathrm{Cu}$, $\mathrm{Zn}, \mathrm{Pb}, \mathrm{Cd}, \mathrm{Fe}$ and $\mathrm{Mn}$ ) were found in the liver and gills of benthic and pelagic fish in the Red Sea, Arabia. The liver tissue is often used as a sample of damage caused by the accumulation of heavy metals in the environment (Amaral et al., 2002). On the basis of the results of the previous research, the heavy metal pollution $(\mathrm{Pb}, \mathrm{Cd}$, and $\mathrm{Cu}$ ) can accumulate in seawater, sediment, and mudskipper bodies in three mangrove areas in the Poka, Waai and Rutong villages. The accumulation of heavy metals can affect the tissue structure of mudskipper to become anomalies. Therefore, the purposes of this research were (1) to analyze the concentration of heavy metals in seawater, sediments and bodies of mudskippers; (2) to analyze the damage to the gill, liver and muscle tissue of mudskipper fish due to the exposure to heavy metals.

\section{MATERIALS AND METHODS}

\section{Study area}

This research was conducted in the waters of Ambon Island, Indonesia (Figure 1). The research locations were at Ferry harbor, Poka (station 1), DPEG (Diesel Power Electricity Generator), Poka (station 2), Waai (station 3), Waai (station 4), Rutong (station 5), Rutong (station 6).

\section{Sample collection}

The samples of water, sediment and mudskipper specimens were collected from each station. Two samples of mudskipper fish were randomly collected from each station. Afterwards, the samples were placed into plastic bags and labeled. The samples were stored in an ice box. All the samples were subsequently taken to the laboratory for analysis.

\section{Sample preparation and analysis of the $\mathrm{Pb}, \mathrm{Cd}$, and $\mathrm{Cu}$}

$\mathrm{The} \mathrm{Pb}, \mathrm{Cd}$, and $\mathrm{Cu}$ heavy metals from all samples were analyzed at Environmental Health and Disease Control Engineering Center - Ambon, Indonesia. The samples were prepared and reconstructed. Then, a calibration curve was created and then analyzed using an Atomic Absorption Spectrophotometer (AAS) to determine each heavy metal. Afterwards, the absorbance from the sample solution was put into the calibration curve, then the amount of $\mu \mathrm{g} \mathrm{Pb}, \mathrm{Cd}$, and $\mathrm{Cu}$ could be calculated (Sirait et al., 2013). The heavy metal content in the sample (wet weight) was calculated by the equation:

$$
\text { Content, } \mathrm{ppm}=a / b
$$

where: $a$-the amount of metal $\mu \mathrm{g}$ from the measurement results with AAS, $b$ - sample weight $(5.0 \mathrm{~g})$. 


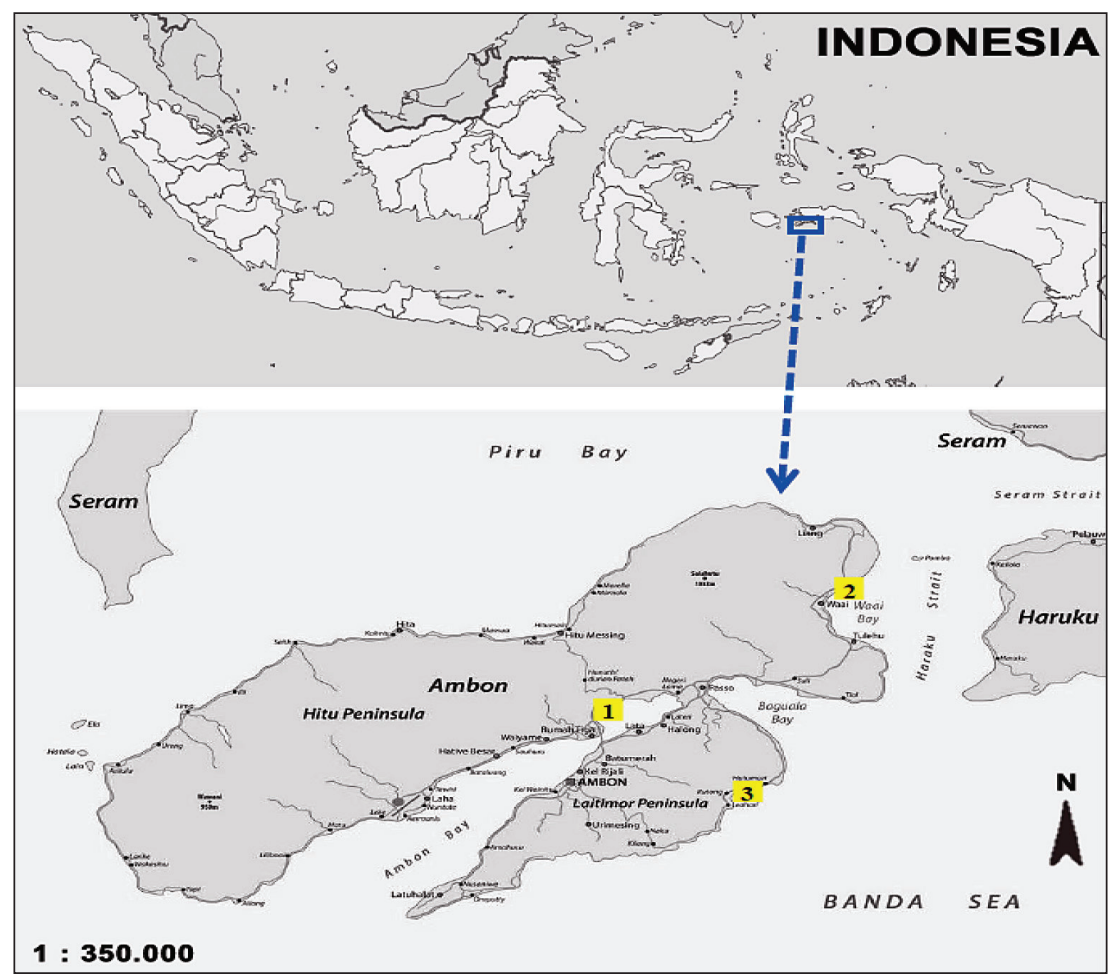

Figure 1. Location of sample collection: 1 - Poka, 2 - Waai, 3 - Rutong station

\section{The histological analysis of the gills, liver and muscles of mudskippers}

The histological preparation followed Chan (2014), with the following steps: (1) the samples were washed and then dissected to separate the gills, liver and muscle; (2) the gills, liver and muscles were then placed in $4 \%$ formalin, and then fixation was carried out for 24 hours; (3) after the fixation, the tissue was dehydrated to alcohol at $70 \%, 80 \%, 90 \%$, absolute, xylol 1 and xylol 2 for 1 hour each; (4) the intestinal tissue was placed in a vacuum to remove air from the tissue; (5) the tissue was molded with a paraffin block, and then thinly sliced using a microtome; (6) the sections were subsequently placed on a waterbath and then removed using a glass object and placed on a hot plate; (7) afterwards, the tools and materials for staining were prepared, including xylol 1 , xylol 2 , absolute alcohol, graded alcohol, hematoxylin solution, eosin solution; (8) the sections were then arranged on a shelf, and placed in xylol 1, xylol 2, absolute alcohol, 90\% alcohol, 80\% alcohol, $70 \%$ alcohol, hematoxylin solution, rinsed with running water for 1 week, eosin solution, rinsed under running water for 1 week, $80 \%$ alcohol, $90 \%$ alcohol, absolute alcohol, xylol 1, and xylol 2. Each solution was added for 3 minutes; (9) the adhesive solution was dropped into a glass object and then covered with a glass cover and observed under a microscope at 40x magnification. Histology description of the mudskipper gills, liver and muscles used the Hematoxylin Eosin (HE) staining method, which was carried out at the Zoology Laboratory, Faculty of Mathematics and Natural Sciences, Pattimura University.

\section{Data analysis}

The data were descriptively analyzed to illustrate the condition of water, sediment and the body tissue histology of the mudskipper that had been exposed to heavy metals. Furthermore, to analyze the effect of heavy metal concentrations on the damage to the gill, liver and muscle tissue of the mudskipper in the Ambon Island waters, the research data were analyzed using correlational analysis to determine the effective contribution of each heavy metal towards the damage of the mudskipper tissue.

\section{RESULTS AND DISCUSSION}

\section{Heavy metal concentrations in the mangrove area}

Table 1 presents the results of the measurements on the $\mathrm{Pb}, \mathrm{Cd}$, and $\mathrm{Cu}$ heavy metals in the 
Table 1. Heavy metal analysis in the fish, sediment and water samples (ppm)

\begin{tabular}{|c|c|c|c|c|c|c|c|c|c|}
\hline \multirow{2}{*}{ Locations } & \multicolumn{4}{|c|}{ Fish } & \multicolumn{3}{c|}{ Sediment } & \multicolumn{3}{c|}{ Seawater } \\
\cline { 2 - 10 } & $\mathrm{Pb}$ & $\mathrm{Cd}$ & $\mathrm{Cu}$ & $\mathrm{Pb}$ & $\mathrm{Cd}$ & $\mathrm{Cu}$ & $\mathrm{Pb}$ & $\mathrm{Cd}$ & $\mathrm{Cu}$ \\
\hline Poka S1 & 0.0038 & 0.0060 & 0.0086 & 0.0055 & 0.0067 & 0.0086 & 0.0057 & 0.0061 & 0.0171 \\
\hline Poka S2 & 0.0019 & 0.0054 & 0.0076 & 0.0052 & 0.0050 & 0.0137 & 0.0055 & 0.0096 & 0.0078 \\
\hline Average & $0.0029 \pm 0.001$ & $0.0057 \pm 0.000$ & $0.0081 \pm 0.000$ & $0.0054 \pm 0.000$ & $0.0059 \pm 0.001$ & $0.0112 \pm 0.003$ & $0.0056 \pm 0.000$ & $0.0079 \pm 0.002$ & $0.0125 \pm 0.007$ \\
\hline Waai S1 & 0.0020 & 0.0068 & 0.0102 & 0.0052 & 0.0055 & 0.0190 & 0.0051 & 0.0100 & 0.0096 \\
\hline Waai S2 & 0.0026 & 0.0052 & 0.0093 & 0.0048 & 0.0067 & 0.0183 & 0.0056 & 0.0089 & 0.0085 \\
\hline Average & $0.0023 \pm 0.000$ & $0.0060 \pm 0.001$ & $0.0098 \pm 0.001$ & $0.0050 \pm 0.000$ & $0.0061 \pm 0.001$ & $0.0187 \pm 0.000$ & $0.0054 \pm 0.000$ & $0.0095 \pm 0.001$ & $0.0091 \pm 0.001$ \\
\hline Rutong S1 & 0.0036 & 0.0059 & 0.0101 & 0.0051 & 0.0049 & 0.0137 & 0.0057 & 0.0086 & 0.0099 \\
\hline Rutong S2 & 0.0033 & 0.0064 & 0.0115 & 0.0055 & 0.0063 & 0.013 & 0.0054 & 0.0072 & 0.0084 \\
\hline Average & $0.0035 \pm 0.000$ & $0.0062 \pm 0.000$ & $0.0108 \pm 0.001$ & $0.0053 \pm 0.000$ & $0.0056 \pm 0.001$ & $0.0134 \pm 0.000$ & $0.0056 \pm 0.000$ & $0.0079 \pm 0.001$ & $0.0092 \pm 0.001$ \\
\hline
\end{tabular}

fish, sediment and seawater samples in the mangrove area of the Ambon Island waters.

The results of the analysis showed that the heavy metals that accumulated in the fish body and sediment in the mangrove area of the Poka, Waai and Rutong villages from the highest to the lowest were $\mathrm{Cu}>\mathrm{Cd}>\mathrm{Pb}$; while the heavy metals that accumulated in the seawater in the mangrove areas of the Poka and Rutong villages were $\mathrm{Cu}>$ $\mathrm{Cd}>\mathrm{Pb}$, whereas the heavy metals that accumulated at the two stations in the mangrove waters of the Waai village were $\mathrm{Cd}>\mathrm{Cu}>\mathrm{Pb}$ (Table 1). The $\mathrm{Cu}$ heavy metal which accumulated more in the fish body can be associated with the fact that $\mathrm{Cu}$ is an essential metal for organisms. $\mathrm{Cu}$ is classified as a transition metal group that has a certain function in the respiration of organisms, but it becomes toxic at high concentrations (Khaled, 2004). Anandkumar et al. (2017) reported that there was a higher increase in the accumulation of essential heavy metals in the bodies of shrimp than that of the accumulation of non-essential heavy metals. The accumulation of heavy metals in the body of fish is influenced by the nature of the heavy metals, the bioavailability, the feeding characteristics, the ecology and the physiology of fish (Perugini et al., 2014). Rainbow (2007) asserts that heavy metal toxicity can occur in living organisms when the accumulation of the heavy metals exceeds the level of metabolic excretion and detoxification of the organisms. Stern (2010) explains that the $\mathrm{Cu}$ heavy metal can be found as a transitional form between oxidized $\mathrm{Cu}$ (II) and reduced $\mathrm{Cu}$ (I) which is toxic because it produces superoxide and hydroxyl radicals. Frazier (1979) explains that $\mathrm{Pb}$ and $\mathrm{Cd}$ are toxic heavy metals, even in low concentrations because they cannot be degraded and can accumulate in the tissues of organisms. Similarly, Dange and Manoj (2015) explain that the concentration of the Cd heavy metal is lower than that of $\mathrm{Cu}$ heavy metal because of the toxicity and the nature of the $\mathrm{Cd}$ heavy metal, which is a non-essential metal for aquatic organisms. Elbay-Poulichet et al. (1987) states that $\mathrm{Cd}$ can be released from its organic complex, by increasing the concentration of $\mathrm{Cl}$ (chlorine), which forms a chloride complex. This research is also supported by the research by Tjahjono and Suwarno (2018) that the concentrations of the $\mathrm{Pb}$ and $\mathrm{Cd}$ heavy metal in the sediments of Demak waters was lower.

The order of the accumulation of the $\mathrm{Pb}$ heavy metal in fish body based on the locations was Rutong village $>$ Poka village $>$ Waai village; while the order of the accumulation of the $\mathrm{Cd}$ and $\mathrm{Cu}$ heavy metal was Rutong $>$ Waai $>$ Poka. The higher average concentrations of $\mathrm{Pb}, \mathrm{Cd}$ and $\mathrm{Cu}$ were reported in the mudskipper fish originating from the mangroves in the Rutong village. This is related to the source of heavy metal pollution in the mangrove area of the Rutong village. Similar results were also reported by Nasr et al. (2006) that the areas with sources of pollution of household wastewater, industrial waste, fishing activities, and fiberglass boat factories tend to have higher accumulation of heavy metals. The research by Rijal et al. (2014) also reported that the $\mathrm{Pb}$ and Cd heavy metal accumulated in the sea waters of the Waai village. Male et al. (2014) emphasizes that the accumulation of the $\mathrm{Pb}$ heavy metal in the Waai waters may be caused by the Tetra Ethyl Lead (TEL) compound in the combustion residue released into the air and then descends into the waters through rain, the place where ships are anchored, oil spills and burning remains of motorboats, resident activities who dispose of garbage in the form of cans, plastics, electric cables, paint cans, used batteries. Meanwhile, the order of heavy metal accumulation in fish, sediment and sea water showed varied results. 
In the mangrove waters of the Poka village, the $\mathrm{Cu}, \mathrm{Cd}$, and $\mathrm{Pb}$ heavy metal accumulated in seawater $>$ sediment $>$ fish. Meanwhile, in the mangrove waters of Waai village, the $\mathrm{Cd}$ and $\mathrm{Pb}$ heavy metal accumulated in seawater $>$ sediment $>$ fish, and the $\mathrm{Cu}$ heavy metal accumulated in sediment> fish $>$ sea water. The mangrove waters of the Rutong Village also showed varied accumulations of heavy metals in seawater, sediment and fish bodies. The $\mathrm{Cd}$ heavy metal accumulated in seawater $>$ fish $>$ sediment, $\mathrm{Cu}$ accumulated in sediments $>$ fish $>$ seawater, and $\mathrm{Pb}$ accumulated in seawater $>$ sediment $>$ fish (Table 1). The high accumulation of $\mathrm{Cu}$ in sediments can be explained by the fact that the organic matter from household waste, leaves, mangrove litter, and carcasses of animals is degraded by detritivores and stays in sediments. This causes the sediments to accumulate high organic matter. Meanwhile, the $\mathrm{Cu}$ heavy metal binds more quickly to organic matter. Similar arguments are also stated by Rath et al. (2009)mineralogy, morphology and multivariate statistical technique for quantifying metal pollution in highly polluted aquatic sediments-a case study: Brahmani and Nandira Rivers, India.","type":"article-journal",,volum e":"163"],"uris":["http://www.mendeley.com/ documents/?uuid=b1e05b46-8dcc-432f-8469-dc 22d26de483"]\}],"mendeley": \{“formattedCitatio n":'(Rath et al., 2009, Mortatti and Probst (2010), and $\mathrm{Yu}$ et al. (2010) that $\mathrm{Cu}$ has a positive correlation with organic matter, so that it has high stability with organic compounds. Moreover, it is also explained that when $\mathrm{Cu}$ is in the form of $\mathrm{Cu}^{2+}$ ion, its affinity greatly increases metal mobility in the sediment. Meanwhile, the accumulation of the $\mathrm{Cu}, \mathrm{Cd}$, and $\mathrm{Pb}$ heavy metal in the mangrove waters of the Poka Village was higher than that in the seawater due to the waste disposal of PLTD (Diesel Power Electricity generator), shipyards and transportation. According to Lee et al. (2016), Sany et al. (2012) and Salleh and Halim (2018), the sources of heavy metals such as paint on ships, ship activity and transportation, and industrial waste can accumulate heavy metals in water. Coban et al. (2009) adds that the heavy metals dissolved in seawater vary and are not constant, depending on the heavy metal elements. The high accumulation of $\mathrm{Cd}$ and $\mathrm{Pb}$ heavy metal in seawater in the mangrove areas of the Waai and Rutong villages is influenced by the activities of motorized vehicles, boat traffic, motorized boats, and various kinds of inorganic waste. The findings of this research are also supported with the research results by Almiqrh et al. (2018) that the high accumulation of $\mathrm{Pb}$ heavy metal was influenced by the research location, which was close to manufacturing factories, so that a lot of factory waste was disposed into the water bodies, and shipping activity. Edokpayi et al. (2015) add that the emissions from cars and poor waste disposal are also sources of heavy metal contamination. Varol and Sen (2012) explain that the sediments containing heavy metals are a secondary source of heavy metal accumulation in aquatic biota.

\section{Damage to gills due to accumulation to heavy metals}

On the basis of the accumulation of heavy metals in the mudskipper fish, histological observations of the gills, liver and muscles were carried out to determine the tissue damage as a physiological response to exposure to these heavy metals. The damage to the gills can be seen in Figure 2. The damage to the gill tissue is characterized by primary lamellar edema, hyperplasia, epithelial desquamation, teleangiectasia, secondary lamellar edema, and clubbing. The types of the gill tissue damage differ among locations. This suggests that heavy metal accumulation can damage the gill tissue. The types of the damage can be visually seen in Figure 2, while the total damage in each location can be seen in Table 2.

It was known that the seawater in the three water locations contained the $\mathrm{Cd}, \mathrm{Cu}$, and $\mathrm{Pb}$ heavy metal. Meanwhile, gills are the respiratory organs of fish, which are immediately exposed to seawater. Therefore, gills are suitable for histological examination to determine the effects of pollution and xenobiotics, because they are the main organs that are directly exposed to seawater (Drishya et al., 2016; Rankin and Jensen, 1993). Camargo and Martinez (2007) add that the histological changes in the gills, kidneys and liver in Prochilodus lineatus indicate that the water flow has been contaminated causing stress effects on fish.

In addition to being a respiratory organ in fish, gills also function as osmotic regulators and excretion organs in the fish body. Evans et al. (2005) state that gills have a function as osmoregulation, gas exchange, excretion, and ion uptake or extrusion, therefore, these organs are ideal for analyzing toxins in aquatic toxicology studies. Thus, gills are representative organs for the analysis of tissue changes due to the heavy metal accumulation in 


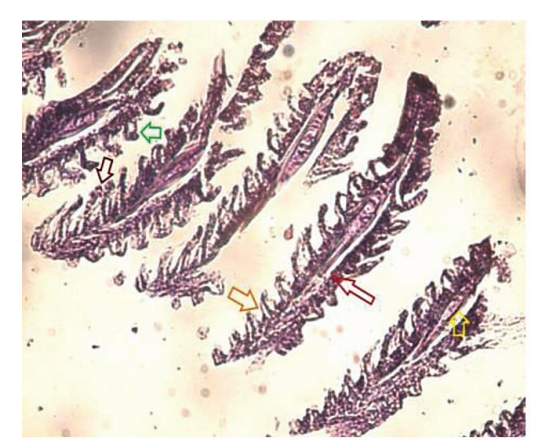

P1

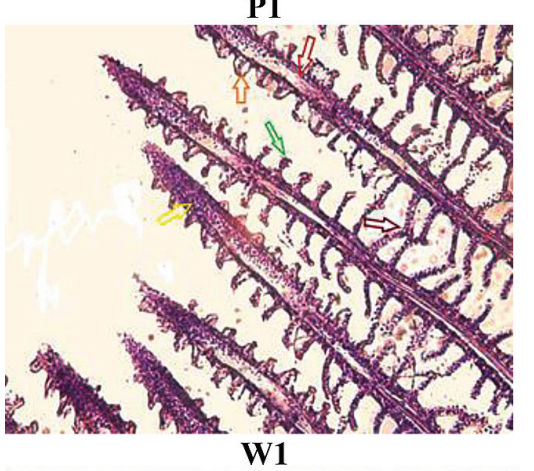

W1

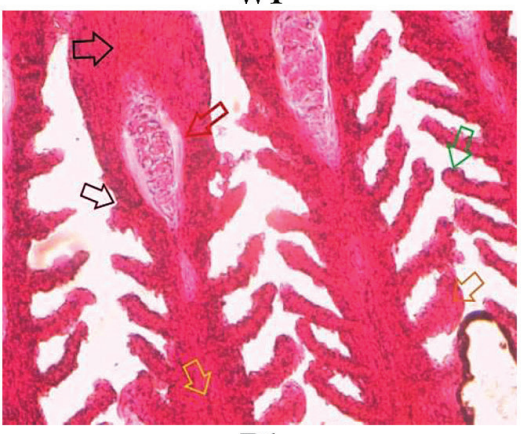

R1

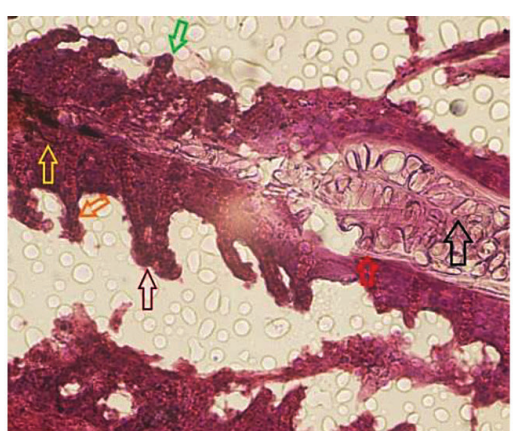

P2

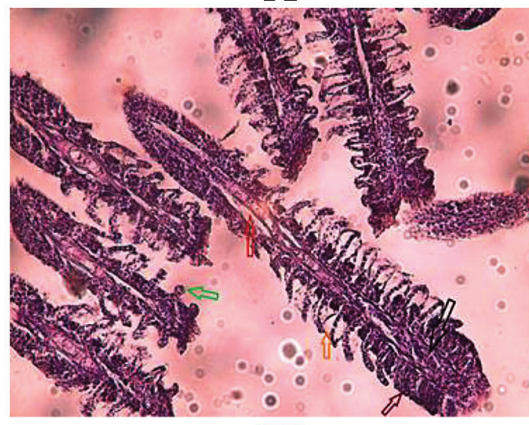

W2

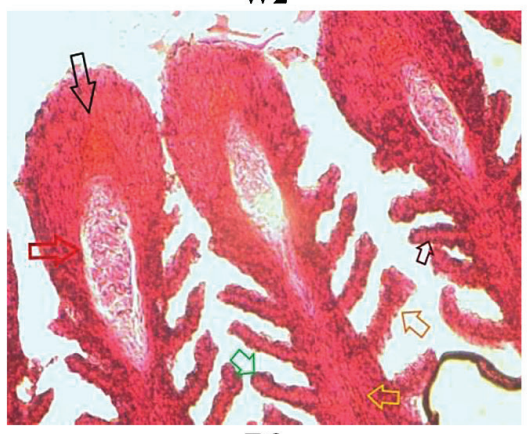

R2

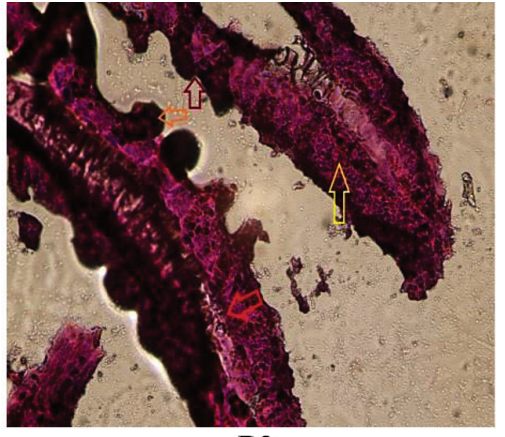

P3

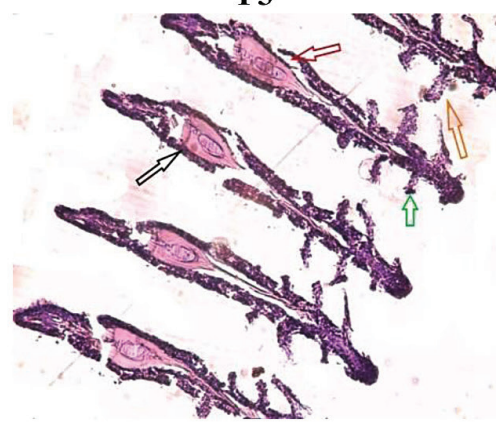

W3

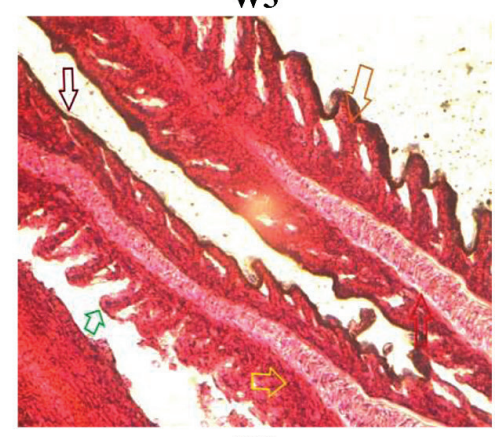

R3

Figure 2. Histological overview of the gill tissue of mudskipper fish. P1, P2, P3 are the locations of Poka stations 1, 2, and 3. W1, W2, W3 are Waai stations 1, 2, and 3. R1, R2, R3 are Rutong stations 1, 2, and 3. Teleangiectasia (green arrows), Secondary Lamela Edema (orange arrows), Hyperplasia (dark red arrows), Epithelial desquamation (red arrows), Clubbing (black arrows), Primary Lamela Edema (yellow arrows). The staining used HE with a magn. of 40×.

Table 2. Calculation of the number of damaged gill cells

\begin{tabular}{|c|c|c|c|c|c|c|c|c|c|c|c|c|c|c|c|c|c|c|c|c|c|c|c|c|c|c|}
\hline \multirow{3}{*}{$\mathrm{L}$} & \multirow{3}{*}{$\begin{array}{l}\text { Pic- } \\
\text { ture }\end{array}$} & \multicolumn{25}{|c|}{ The number of damaged gill } \\
\hline & & \multicolumn{5}{|c|}{ I } & \multicolumn{6}{|c|}{ II } & \multicolumn{5}{|c|}{ III } & \multicolumn{6}{|c|}{ IV } & \multicolumn{3}{|c|}{ V } \\
\hline & & PLE & $\mathrm{H}$ & $\mathrm{D}$ & SLE & $T$ & PLE & $\mathrm{H}$ & $\mathrm{D}$ & SLE & $T$ & C & PLE & $\mathrm{H}$ & D & SLE & $T$ & PLE & $\mathrm{H}$ & $\mathrm{D}$ & SLE & $T$ & $C$ & PLE & $\mathrm{D}$ & C \\
\hline \multirow[b]{4}{*}{ r } & 1 & 6 & 5 & 1 & 0 & 2 & 6 & 4 & 0 & 0 & 4 & & 0 & 22 & 0 & & 1 & 3 & 3 & 1 & 0 & 2 & & 1 & 1 & 0 \\
\hline & 2 & 2 & 4 & 0 & 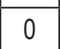 & 0 & 1 & 5 & 1 & 5 & 4 & & 2 & 0 & 1 & & 0 & 0 & 0 & 1 & 0 & 0 & & 0 & 0 & 1 \\
\hline & 3 & 1 & 3 & 0 & 3 & 0 & 0 & 3 & 0 & 4 & 4 & & 1 & 6 & 0 & & 0 & 1 & 3 & 0 & 3 & 3 & & 1 & 0 & 0 \\
\hline & \begin{tabular}{|l|} 
Ave- \\
rage \\
\end{tabular} & $\begin{array}{l}3.0 \pm \\
2.65 \\
\end{array}$ & $\begin{array}{c}4.0 \pm \\
1.0 \\
\end{array}$ & $\begin{array}{c}1.0 \pm \\
0.6 \\
\end{array}$ & \begin{tabular}{|c|}
$3.0 \pm$ \\
1.7 \\
\end{tabular} & \begin{tabular}{|c|}
$2.0 \pm$ \\
1.1 \\
\end{tabular} & \begin{tabular}{|c}
$3.5 \pm$ \\
3.2 \\
\end{tabular} & $\begin{array}{c}4.0 \pm \\
1.0 \\
\end{array}$ & $\begin{array}{c}1.0 \pm \\
0.6 \\
\end{array}$ & $\begin{array}{c}4.5 \pm \\
2.7 \\
\end{array}$ & $\begin{array}{c}4.0 \pm \\
1.0 \\
\end{array}$ & & \begin{tabular}{|c|}
$1.5 \pm$ \\
1.0 \\
\end{tabular} & $\begin{array}{c}14.0 \pm \\
11.4 \\
\end{array}$ & $\begin{array}{c}1.0 \pm \\
0.9 \\
\end{array}$ & & \begin{tabular}{|c|}
$1.0 \pm$ \\
0.6 \\
\end{tabular} & $\begin{array}{c}2.0 \pm \\
1.5 \\
\end{array}$ & \begin{tabular}{|c|}
$3.0 \pm$ \\
1.7 \\
\end{tabular} & \begin{tabular}{c|}
$1.0 \pm$ \\
0.6 \\
\end{tabular} & $\begin{array}{c}3.0 \pm \\
1.7 \\
\end{array}$ & $\begin{array}{c}2.5 \pm \\
1.5 \\
\end{array}$ & & \begin{tabular}{|c|}
$1.0 \pm$ \\
0.6 \\
\end{tabular} & $\begin{array}{c}1.0 \pm \\
0.6\end{array}$ & $=\begin{array}{c}1.0 \pm \\
0.6\end{array}$ \\
\hline \multirow[b]{4}{*}{$\begin{array}{l}A \\
r\end{array}$} & 1 & 1 & 0 & 0 & 7 & 7 & & 0 & 0 & 0 & 7 & & & 3 & 0 & 0 & 5 & 0 & 0 & 1 & 5 & 6 & 0 & 0 & 4 & \\
\hline & 2 & 0 & 15 & 2 & 0 & 0 & & 7 & 0 & 6 & 4 & & & 7 & 0 & 7 & 6 & 0 & 25 & 1 & 3 & 6 & 1 & 0 & 4 & \\
\hline & 3 & 1 & 30 & 0 & 0 & 0 & & 10 & 1 & 0 & 0 & & & 10 & 1 & 0 & 0 & 1 & 5 & 0 & 3 & 0 & 1 & 1 & 2 & \\
\hline & \begin{tabular}{|l|} 
Ave- \\
rage \\
\end{tabular} & $\begin{array}{c}1.0 \pm \\
0.6 \\
\end{array}$ & $\begin{array}{l}22 . \pm \\
15.0 \\
\end{array}$ & $2.0 \pm$ & \begin{tabular}{|c|}
$7.0 \pm$ \\
4.0 \\
\end{tabular} & \begin{tabular}{|c|}
$7.0 \pm$ \\
4.0 \\
\end{tabular} & & \begin{tabular}{|c|}
$8.5 \pm$ \\
5.1 \\
\end{tabular} & $\begin{array}{c}1.0 \pm \\
0.6 \\
\end{array}$ & $\begin{array}{c}6.0 \pm \\
3.5 \\
\end{array}$ & \begin{tabular}{|c|}
$5.5 \pm$ \\
3.5 \\
\end{tabular} & & & \begin{tabular}{|c|}
$6.7 \pm$ \\
3.5 \\
\end{tabular} & $\begin{array}{c}1.0 \pm \\
0.6 \\
\end{array}$ & $\begin{array}{c}7.0 \pm \\
4.0\end{array}$ & $\begin{array}{c}5.5 \pm \\
3.2 \\
\end{array}$ & \begin{tabular}{c|}
$1.0 \pm$ \\
0.6
\end{tabular} & $\begin{array}{c}15.0 \pm \\
13.3 \\
\end{array}$ & \begin{tabular}{c|}
$1.0 \pm$ \\
0.6
\end{tabular} & \begin{tabular}{|c|}
$3.7 \pm$ \\
1.2 \\
\end{tabular} & \begin{tabular}{|c|}
$6.0 \pm$ \\
3.5 \\
\end{tabular} & $\begin{array}{c}1.0 \pm \\
0.6\end{array}$ & $\begin{array}{c}1.0 \pm \\
0.6 \\
\end{array}$ & \begin{tabular}{|c|}
$3.3 \pm$ \\
1.2 \\
\end{tabular} & \\
\hline & 1 & & 0 & & 3 & & 2 & 3 & 2 & 0 & & 1 & 2 & 0 & & 3 & 3 & 1 & 0 & & 2 & 0 & & 1 & 0 & \\
\hline & 2 & & 0 & & 2 & & 2 & 3 & 2 & 0 & & 1 & 0 & 0 & & 3 & 1 & 2 & 0 & & 2 & 2 & & 1 & 0 & \\
\hline & 3 & & 6 & & 6 & & 0 & 6 & 0 & 6 & & 0 & 0 & 5 & & 5 & 0 & 0 & 7 & & 7 & 0 & & 0 & 2 & \\
\hline & \begin{tabular}{|l|} 
Ave- \\
rage
\end{tabular} & & \begin{tabular}{|c|}
$6.0 \pm$ \\
3.5
\end{tabular} & & \begin{tabular}{|c|}
$3.7 \pm$ \\
2.1 \\
\end{tabular} & & $\begin{array}{c}2.0 \pm \\
1.2\end{array}$ & $\begin{array}{c}4.0 \pm \\
1.7\end{array}$ & $\begin{array}{c}2.0 \pm \\
1.2\end{array}$ & $\begin{array}{c}6.0 \pm \\
3.5 \\
\end{array}$ & & \begin{tabular}{|c|}
$1.0 \pm$ \\
0.6
\end{tabular} & $\begin{array}{c}2.0 \pm \\
1.2\end{array}$ & $\begin{array}{c}5.0 \pm \\
2.9\end{array}$ & & \begin{tabular}{|c|}
$3.7 \pm$ \\
1.2
\end{tabular} & $2.0 \pm$ & \begin{tabular}{|c|}
$1.5 \pm$ \\
1.0 \\
\end{tabular} & $\begin{array}{c}7.0 \pm \\
4.0\end{array}$ & & \begin{tabular}{|c|}
$3.7 \pm$ \\
2.9
\end{tabular} & \begin{tabular}{c|}
$2.0 \pm$ \\
1.2
\end{tabular} & & $\begin{array}{c}1.0 \pm \\
0.6\end{array}$ & \begin{tabular}{|c|}
$2.0 \pm$ \\
1.2
\end{tabular} & \\
\hline
\end{tabular}

Note: PLE - primary lamella edema, H - Hyperplasia, D - epithelial desquamation, SLE - secondary lamella edema, T - teleangiectasia, C - clubbing, L - locations, P - Poka stations, W - Waai stations, R - Rutong stations. 
seawater. One of the striking changes that occur in the gills of mudskipper fish is primary lamella edema and hyperplasia. Hyperplasia is a histological condition in fish gills characterized by secondary lamella thickening and secondary lamella cell fusion due to abnormal cell division. Lujic et al. (2013) stated that hyperplasia causes a reduction in the respiratory surface and removal of the epithelium which affects the water absorption and blood circulation, and it also triggers a gill defense mechanism when exposed to pollutants. However, these changes can lead to respiratory distress. Hyperplasia can cause disruption of the respiratory system of fish, because the secondary lamellae cells are fused and adjoined.

Primary lamellae edema is a condition of swelling in the primary lamellae of the gills which functions to supply blood to and from the secondary lamella. This swelling can disrupt the function of the primary lamellae. Fadaeifard and Azizi (2014) added that the thickening of the lamellae is a form of defense that reduces the surface area of the lamella branches exposed to the external environment. In addition, there is also a condition of teleangiectasia, where the tip of the secondary lamellae is ball-like, causing a buildup of red blood cells due to the damage to the pillar cells that make up the secondary lamellae. Bhagwant and Elahee (2002) added that the teleangiectasia condition observed in Mulloidichthys flavolineatus and Mugil cephalus could affect blood circulation, causing respiratory problems. The research by Oliva et al. (2013) showed that there was a correlation between the $\mathrm{Pb}$ heavy metal and changes in gill histology such as hypertrophy, hyperplasia, and epithelial thickening of the lamellae.

The research conducted by Rajeshkumar and Li (2018) reports that the gills of Pelteobagrus fluvidraco and Cyprinus carpio accumulate heavy metals due to the binding of metals with mucus which is difficult to separate. Similarly, the research conducted by Dane and Sisman (2015) shows that the accumulation of the $\mathrm{Cd}, \mathrm{Al}, \mathrm{As}$, $\mathrm{Pb}$, and $\mathrm{Mn}$ heavy metal may cause disturbance to the gills such as hypertrophy, hyperplasia, thickening of the lamellae, vasodilation, congestion and fusion. The research by Flores-Lopes and Thomaz (2011) shows that as a result of epithelial desquamation, there is an increase in the distance between water and blood, which disrupts the oxygen absorption. Similar research results were also reported by Khabbazi et al. (2015) that the absorption of copper can cause changes in the gills of rainbow fish, namely epithelial hypertrophy, hyperplasia, fusion of lamellae and aneurysms and edema in the gills.

\section{Liver damage due to accumulation to heavy metals}

The types of liver damage among locations vary. This shows that the accumulation of heavy metals can damage liver tissue. The type of damage can be visually seen in Figure 3, while the total damage for each location can be seen in Table 3 .

Heavy metals can accumulate not only in the gills of mudskipper fish, but also in other fish tissues, such as liver and muscle. Therefore, the histological changes that occur in the gills can also occur in the liver and muscles. Dane and Sisman (2015) add that when absorbing heavy metals, fish can accumulate the heavy metals efficiently in various. The histological changes in the mudskipper liver are hemorrhage and fatty degeneration. Changes in the liver serve as a marker that fish have been exposed to a stressful environment (Velmurugan et al., 2009; Figueiredo-Fernandes et al., 2007). The liver is a multifunctional organ. The liver has a function to perform the metabolic processes of fat, protein, carbohydrates; nutrient distribution; and detoxification of toxic metabolites, drugs and xenobiotics, so that drugs, alcohol, and xenobiotics can damage liver cells (Chiang, 2014; Gulati et al., 2018; Mitra and Metcalf, 2009). The physiological function of the liver as detoxification causes this organ to be used as a biomarker of environmental quality. Bu-Olayan and Thomas (2008) argue that liver has the highest accumulation of heavy metals, because it functions as a detoxifier, while the accumulation of heavy metals in muscles is due to the absorption of heavy metal residues through the intestinal walls. In turn, the accumulation that occur in gills is due to the formation of metal complexes with mucus in the gill lamellae. Camargo and Martinez (2007) added that the detoxification and biotransformation processes of the liver make this organ the most vulnerable to the damage caused by various toxins.

As a biomarker of environmental quality, the liver of mudskippers in this research experienced some changes, such as fat degeneration and hemorrhage in hepatocytes. The research by Oliva et al. (2013) revealed that necrosis in the liver has a correlation with the accumulation of the As, $\mathrm{Cd}$, and $\mathrm{Cu}$ heavy metal in water. The results of this 


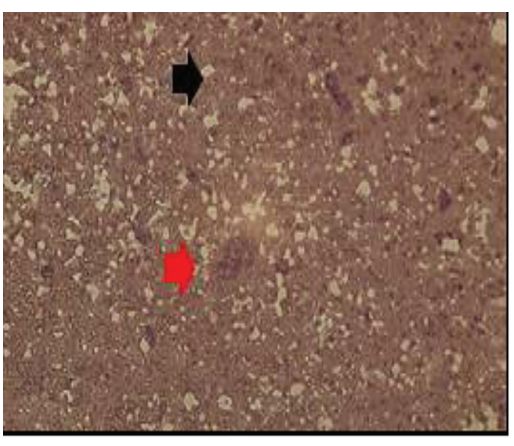

P1

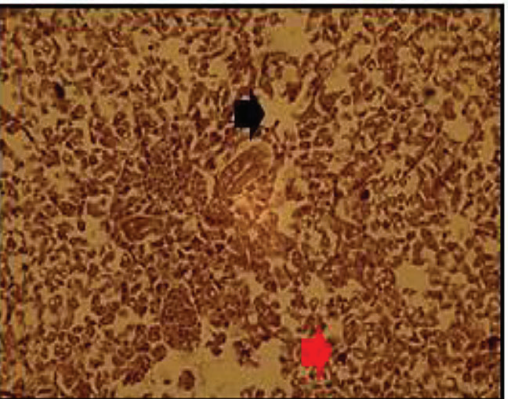

W1

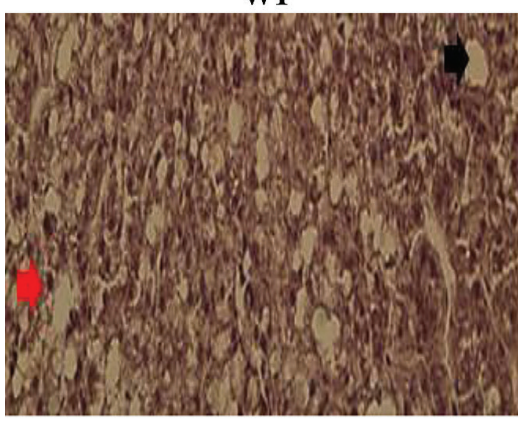

R1

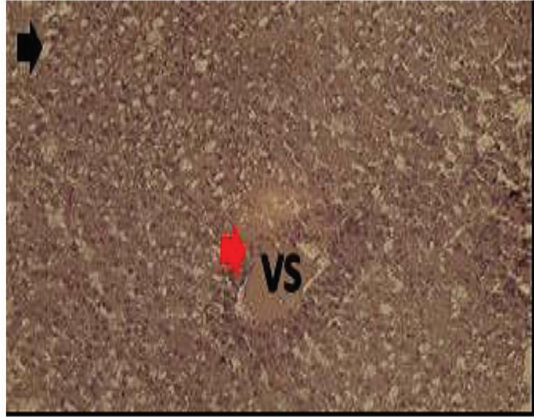

P2

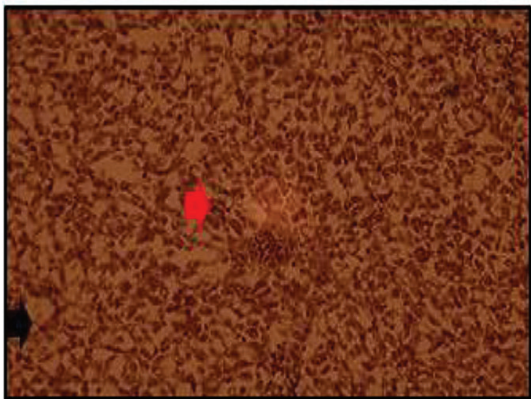

W2

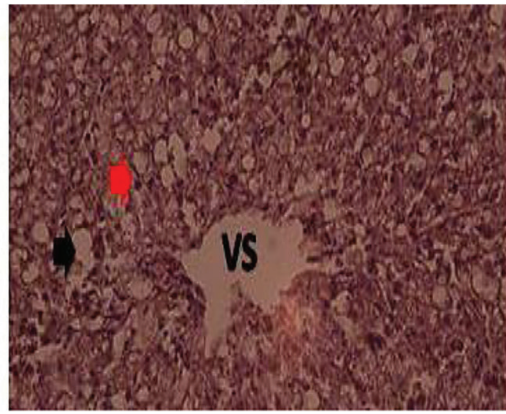

R2

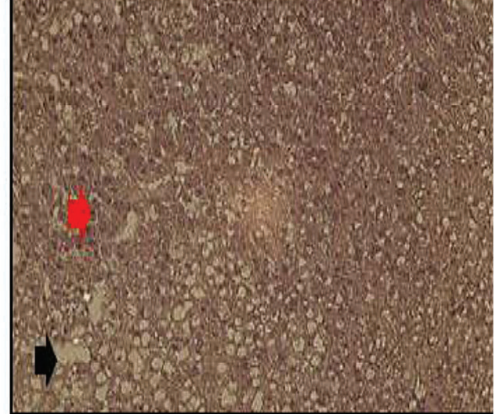

P3

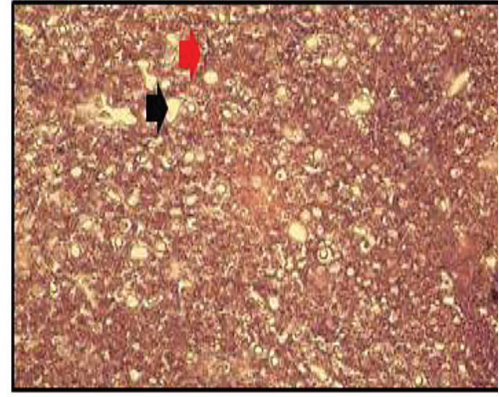

W3

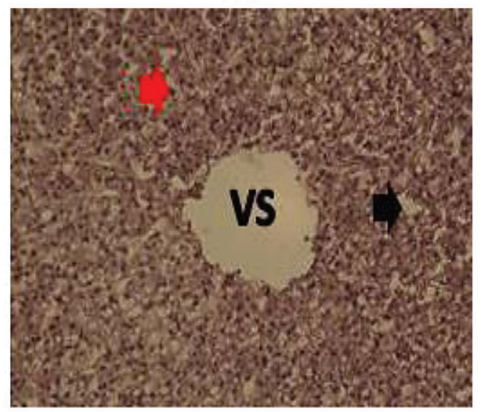

R3

Figure 3. Histological overview of the liver tissue of the mudskipper fish. P1, P2, P3 are the locations of Poka station 1, station 2, and station 3. W1, W2, W3 are Waai station 1, station 2, and station 3. R1, R2, R3 are Rutong station 1, station 2, and station 3. Vena Sentralis (VS), Hemorrhage (red arrows), Fatty degeneration (black arrows). Staining used HE with a magnification of $40 \times$.

Table 3. Calculation of the number of damaged liver cells

\begin{tabular}{|c|c|c|c|c|c|c|c|c|c|c|c|}
\hline \multirow{3}{*}{ L } & \multirow{3}{*}{ Figure } & \multicolumn{10}{|c|}{ The number of damaged liver } \\
\hline & & \multicolumn{2}{|c|}{1} & \multicolumn{2}{|c|}{ II } & \multicolumn{2}{|c|}{ III } & \multicolumn{2}{|c|}{ IV } & \multicolumn{2}{|c|}{ V } \\
\hline & & $\mathrm{H}$ & FT & $\mathrm{H}$ & FT & $\mathrm{H}$ & FT & $\mathrm{H}$ & FT & $\mathrm{H}$ & FT \\
\hline \multirow{4}{*}{$P$} & 1 & 82 & 38 & 42 & 24 & 51 & 28 & 62 & 28 & 40 & 47 \\
\hline & 2 & 136 & 35 & 152 & 25 & 123 & 19 & 67 & 21 & 126 & 13 \\
\hline & 3 & 77 & 34 & 85 & 23 & 66 & 62 & 69 & 44 & 93 & 47 \\
\hline & Average & $98.33 \pm 32.72$ & $35.67 \pm 2.08$ & $93.00 \pm 55.43$ & $24.00 \pm 1.00$ & $80.00 \pm 37.99$ & $36.33 \pm 22.68$ & $66.00 \pm 3.61$ & $31.00 \pm 11.79$ & $86.33 \pm 43.39$ & $35.67 \pm 19.63$ \\
\hline \multirow{4}{*}{ W } & 1 & 55 & 30 & 33 & 32 & 42 & 34 & 42 & 32 & 80 & 35 \\
\hline & 2 & 71 & 31 & 61 & 29 & 42 & 35 & 44 & 32 & 60 & 40 \\
\hline & 3 & 44 & 14 & 50 & 13 & 50 & 14 & 25 & 21 & 46 & 21 \\
\hline & Average & $56.67 \pm 13.58$ & $25.00 \pm 9.54$ & $48.00 \pm 14.11$ & $24.67 \pm 10.21$ & $44.67 \pm 4.62$ & $27.67 \pm 11.85$ & $37.00 \pm 10.40$ & $28.33 \pm 6.35$ & $62.00 \pm 17.09$ & $32.00 \pm 9.85$ \\
\hline \multirow{4}{*}{$\mathrm{R}$} & 1 & 59 & 19 & 78 & 7 & 46 & 17 & 43 & 7 & 49 & 18 \\
\hline & 2 & 73 & 32 & 79 & 28 & 70 & 23 & 77 & 16 & 95 & 14 \\
\hline & 3 & 118 & 14 & 82 & 31 & 147 & 28 & 130 & 24 & 159 & 17 \\
\hline & Average & $83.33 \pm 30.83$ & $21.67 \pm 9.29$ & $79.67 \pm 2.082$ & $22.00 \pm 13.08$ & $87.67 \pm 52.77$ & $22.67 \pm 5.51$ & $83.30 \pm 43.8$ & $15.67 \pm 8.51$ & $101.00 \pm 55.24$ & $16.33 \pm 2.08$ \\
\hline
\end{tabular}

Note: $\mathrm{H}$ - hemorrhage, FD - fatty degeneration, L - locations, P - Poka stations, W - Waai stations, R - Rutong stations. 
research also indicated that the $\mathrm{Cd}, \mathrm{Cu}$, and $\mathrm{Pb}$ heavy metals were accumulated with varying concentrations at three locations. According to Godt et al. (2006), the chemical and physical characteristics of the Cd heavy metals are similar to those of the essential metals such as $\mathrm{Fe}, \mathrm{Zn}$ or $\mathrm{Ca}$, and thus it can be bound and incorporated into cells by "ionic" and "molecular mimicry" processes.

Several research results have shown changes in fish livers. The research by Hadi and Alwan (2012) also shows changes in the liver tissue of Tilapia zillii in the form of hypertrophy of hepatocytes, and blood congestion in the central veins. Ishibashi et al. (2009) adds that the tissue damage caused by various xenobiotics can cause fibrosis, inflammation, and necrosis, thus affecting the normal liver morphological structure and deteriorating the metabolic function of the liver. Ardeshir et al. (2017) the presence of heavy metals in the liver tissue causes oxidative stress and an increase in reactive oxygen species (ROS) through the induction of oxygen and the transformation of oxygen into superoxide, hydrogen peroxide and hydroxyl radicals. Meanwhile, these hydroxyl radicals are able to bind to various compounds. The research by Abalaka (2015) also reported that the liver histology of the Auchenoglanis occidentalis fish exposed to heavy metals showed hemorrhage. Mustafa et al. (2017) also reported that the liver of the Cyprinus carpio L. fish exposed to high concentrations of $\mathrm{Pb}$ showed a necrotic condition with nuclear picnosis.

Jan et al. (2015) and Arroyo et al. (2012) added that after $\mathrm{Pb}$ and $\mathrm{Cd}$ were absorbed in the intestinal epithelium, the heavy metals were then bound with blood and circulated to the liver tissue. This condition causes changes in hemorrhage and fatty degeneration of the liver. The research by Kaur et al. (2018) also showed the histology of the liver with hemorrhage, necrosis, vacuolization of hepatocytes, degeneration of the nucleus, and the presence of macrophages. Fatima and Usamani (2013) reported histological conditions of liver tissue vacuolization, picnosis, and rupture of blood vessels and bleeding due to the exposure to heavy metals.

The higher accumulation of heavy metals in the liver of Tilapia ziilii than that in the liver of Clarias gariepinus and Mugil cephalus is likely because Tilapia ziilii has higher tolerance to heavy metals than the other species (AbdelSatar and Shehata, 2000). Furthermore, Ahmed et al. (2017) reported that the accumulation of heavy metals in the liver, kidneys and gills of Anodontostoma chacunda was higher than that in the muscle tissue. The lowest accumulation of heavy metals was found in muscle, while the highest accumulation was found in liver or gills (Amundsen et al., 1997; Al-Yousuf et al., 2000; Yilmaz, 2009).

\section{Muscle damage due to accumulation to heavy metals}

Muscle damage can be seen in Figure 4. The damage to the muscle tissue is characterized by the changes in muscle fibers, edema and necrosis. The types of muscle tissue damage also vary among locations. This suggests that the accumulation of heavy metals can damage muscle tissue. Figure 4 shows visual damage types, while the total damage for each location can be seen in Table 4 .

Although the accumulation of heavy metals in muscles was slightly lower than that in liver and gills, the exposure to heavy metals $\mathrm{Cd}, \mathrm{Cu}$, and $\mathrm{Pb}$ in this research also resulted in histological changes in the muscles of the mudskipper fish. The changes in muscles included the changes in muscle fibers, edema, and necrosis. Kaoud and El-Dahshan (2010) reported that muscle degeneration occurred in tilapia due to the exposure to $\mathrm{Cu}, \mathrm{Cd}, \mathrm{Pb}$, and $\mathrm{Hg}$ heavy metals. Similar research results were also reported by Patnaik et al. (2011) that the accumulation of $\mathrm{Pb}$ and $\mathrm{Cd}$ causes the thickening and separation of muscle bonds and intramuscular edema. Krishnamoorthy and Nagarajan (2013) reported that the fish exposed to heavy metals showed the thickening and separation of muscle bonds characterized by severe intracellular edema. Bhuvaneshwari et al. (2015) vacuolar degeneration and atrophy in muscle fibers are caused by a mixture of various types and concentrations of heavy metals. Maftuch et al. (2018) argue that the necrosis that occurs in the muscle tissue can cause muscles to lose their function and nature. The results of this research are also supported with the research results by Sia-Su et al. (2013) stating that the accumulation of heavy metals can cause the disintegration of muscle fibers, causing gaps between each muscle bond. Kaoud and El-Dahshan (2010) added that the fish muscles exposed to heavy metals showed changes in muscle fibers through atrophy and separation of muscle fibers. 


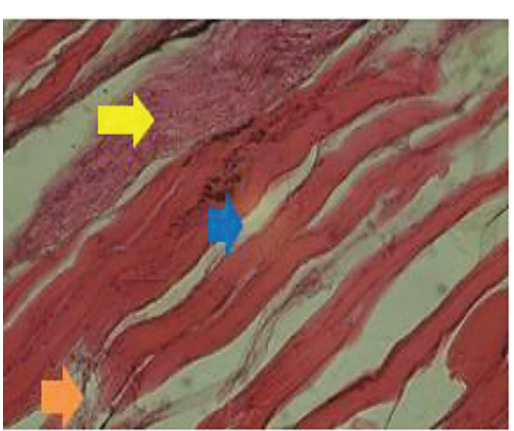

P1

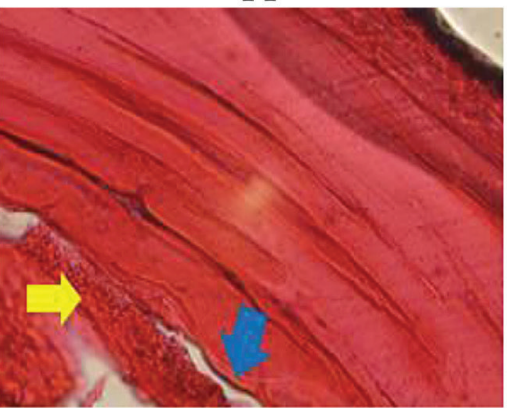

W1

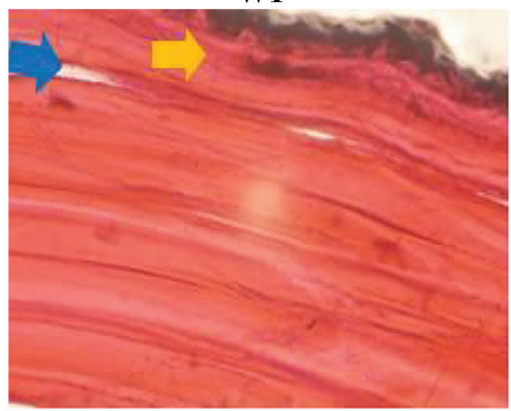

R1

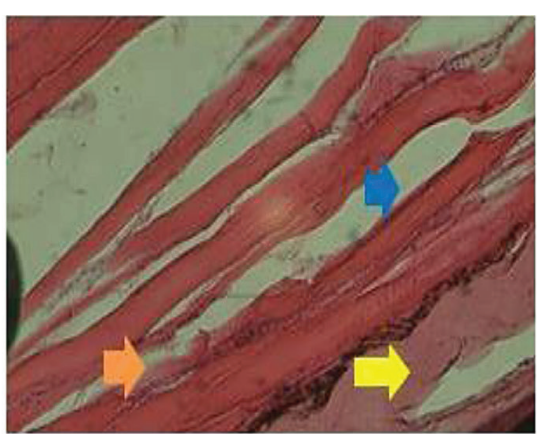

P2

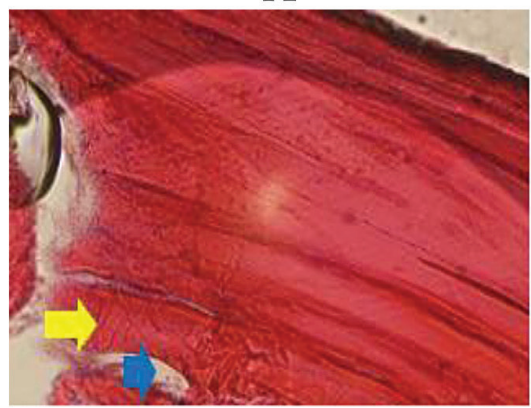

W2

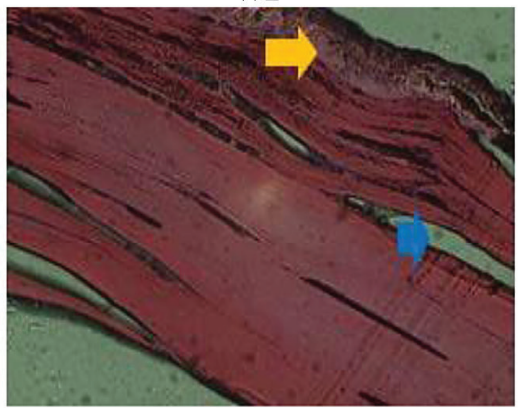

R2

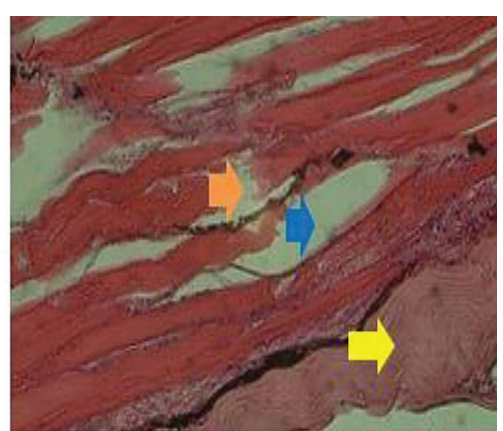

P3

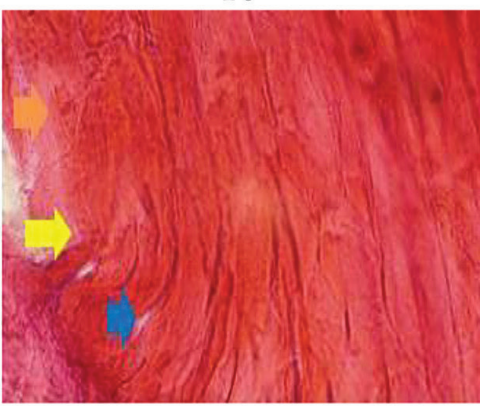

W3

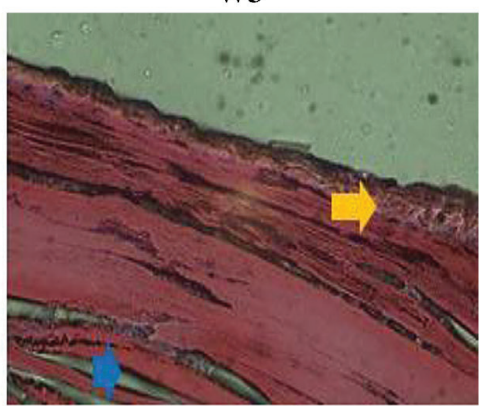

R3

Figure 4. Histological overview of the muscle tissue of the mudskipper fish. P1, P2, P3 are the locations at Poka station 1, station 2, and station 3. W1, W2, W3 are Waai station 1, station 2, and station 3. R1, R2, R3 are Rutong station 1, station 2, and station 3. The changes involved muscle fibers (yellow arrows), edema (blue arrows), necrosis (orange arrows). Staining used HE with a magnification of $40 \times$.

Table 4. Calculation of the number of muscle cells experiencing damage

\begin{tabular}{|c|c|c|c|c|c|c|c|c|c|c|c|c|c|}
\hline \multirow{3}{*}{$\begin{array}{l}\text { Loca- } \\
\text { tions }\end{array}$} & \multirow{3}{*}{ Figure } & \multicolumn{12}{|c|}{ The number of damaged muscle } \\
\hline & & \multicolumn{3}{|c|}{ I } & \multicolumn{2}{|c|}{$\|$} & \multicolumn{2}{|c|}{ III } & \multicolumn{3}{|c|}{ IV } & \multicolumn{2}{|c|}{$\mathrm{V}$} \\
\hline & & PSO & $E$ & $\mathrm{~N}$ & PSO & $\mathrm{N}$ & PSO & $E$ & PSO & $E$ & $\mathrm{~N}$ & PSO & $\mathrm{N}$ \\
\hline \multirow{4}{*}{ Poka } & 1 & 1 & 0 & 0 & 1 & 0 & 1 & 0 & 1 & 1 & 0 & 1 & 0 \\
\hline & 2 & 1 & 0 & 1 & 1 & 0 & 1 & 0 & 0 & 0 & 1 & 1 & 0 \\
\hline & 3 & 1 & 2 & 0 & 1 & 1 & 0 & 2 & 0 & 0 & 1 & 0 & 1 \\
\hline & Average & $1.00 \pm 0.00$ & $2.00 \pm 1.16$ & $1.00 \pm 0.58$ & $1.00 \pm 0.00$ & $1.00 \pm 0.58$ & $1.00 \pm 0.58$ & $2.00 \pm 1.17$ & $1.00 \pm 0.58$ & $1.00 \pm 0.58$ & $1.00 \pm 0.58$ & $1.00 \pm 0.58$ & $1.00 \pm 0.58$ \\
\hline \multirow{4}{*}{ Waai } & 1 & 1 & 1 & & 1 & & 1 & 1 & 1 & & & 1 & \\
\hline & 2 & 1 & 1 & & 1 & & 1 & 0 & 1 & & & 1 & \\
\hline & 3 & 1 & 2 & & 1 & & 1 & 0 & 1 & & & 1 & \\
\hline & Average & $1.00 \pm 0.00$ & $1.33 \pm 0.58$ & & $1.00 \pm 0.00$ & & $1.00 \pm 0.00$ & $1.00 \pm 0.58$ & $1.00 \pm 0.00$ & & & $1.00 \pm 0.00$ & \\
\hline \multirow{4}{*}{ Rutong } & 1 & 1 & 1 & & 1 & & 1 & 0 & 1 & 1 & & 1 & \\
\hline & 2 & 1 & 0 & & 1 & & 1 & 1 & 1 & 1 & & 1 & \\
\hline & 3 & 1 & 0 & & 1 & & 1 & 1 & 1 & 0 & & 1 & \\
\hline & Average & $1.00 \pm 0.00$ & $1.00 \pm 0.58$ & & $1.00 \pm 0.00$ & & $1.00 \pm 0.00$ & $1.00 \pm 0.58$ & $1.00 \pm 0.00$ & $1.00 \pm 0.58$ & & $1.00 \pm 0.00$ & \\
\hline
\end{tabular}

Note: $\mathrm{CMF}$ - changes in muscle fibers, $\mathrm{E}$ - edema, $\mathrm{N}$ - necrosis. 


\section{The correlation between the accumulation of heavy metals and damage to gills, liver and muscles}

The results of the correlation analysis between $\mathrm{Cu}, \mathrm{Cd}$, and $\mathrm{Pb}$ towards the damage to gills, liver and muscles are presented in Table 5. These results showed that there was a correlation between fish, sea water and sediment towards the accumulation of heavy metals in the target organs of gills, liver and muscles (Table 4). On the basis of the data of the determination coefficient (R), the effective contribution of the medium of heavy metal accumulation such as fish, sea water and sediment (Table 4) can be explained. The results of the analysis showed that the sea water, sediment, and fish had a very high effective contribution towards the accumulation of $\mathrm{Cu}, \mathrm{Pb}$ and $\mathrm{Cd}$ in the target organs of gills and liver. Meanwhile, the highest accumulation of $\mathrm{Cu}$ was due to the effective contribution of sea water. The results of this research indicate that the accumulation of heavy metals in target organs through sea water, sediment and fish varies. The effective contribution of sea water towards the accumulation of the three heavy metals was $\mathrm{Cu}$ in muscles $>\mathrm{Pb}$ in gills $>\mathrm{Cd}$ in the liver. The effective contribution of fish towards the accumulation of the three heavy metals was $\mathrm{Cu}$ in the liver $>\mathrm{Pb}$ in the gills $>$ $\mathrm{Cd}$ in the liver. The effective contribution of sediment towards the accumulation of the three heavy metals was $\mathrm{Cu}$ in the gills $>\mathrm{Cd}$ in the liver $>\mathrm{Pb}$ in the liver (Table 5).

Sea water is a medium for the accumulation of $\mathrm{Pb}, \mathrm{Cd}$, and $\mathrm{Cu}$ in muscles, gills and liver. This is because gills are directly exposed to sea water. Javed and Usmani (2011) add that fish gills bind oxygen from sea water, so that the accumulation of heavy metals in the gills due to the sea water is very high. Therefore, the $\mathrm{Pb}$ which dissolves in water will indirectly accumulate in the body of fish through the gills. According to Hapsari et al. (2017), the highest accumulation of $\mathrm{Pb}$ was found in the gills of Nemipterus sp. compared to its muscle and skin. Gills take ions from seawater for respiration, making the gills to be the

Table 5. The correlation between the accumulation of heavy metals and the target organs

\begin{tabular}{|c|c|c|c|c|c|}
\hline Heavy metals & Heavy metal medium & Target organs & $\mathrm{R}$ & $\mathrm{R}^{2}$ & Effective contribution (\%) \\
\hline \multirow{9}{*}{$\mathrm{Pb}$} & \multirow{3}{*}{ Fish } & Gills & 0.635 & 0.403 & 40.3 \\
\hline & & Liver & 0.507 & 0.257 & 25.7 \\
\hline & & Muscles & 0.682 & 0.466 & 46.6 \\
\hline & \multirow{3}{*}{ Seawater } & Gills & 0.845 & 0.714 & 71.4 \\
\hline & & Liver & 0.616 & 0.379 & 37.9 \\
\hline & & Muscles & 0.675 & 0.456 & 45.6 \\
\hline & \multirow{3}{*}{ Sediment } & Gills & 0.296 & 0.087 & 8.7 \\
\hline & & Liver & 0.412 & 0.17 & 17 \\
\hline & & Muscles & 0.205 & 0.042 & 4.2 \\
\hline \multirow{9}{*}{$\mathrm{Cd}$} & \multirow{3}{*}{ Fish } & Gills & 0.412 & 0.170 & 17 \\
\hline & & Liver & 0.369 & 0.136 & 13.6 \\
\hline & & Muscles & 0.186 & 0.034 & 3.4 \\
\hline & \multirow{3}{*}{ Seawater } & Gills & 0.544 & 0.296 & 29.6 \\
\hline & & Liver & 0.815 & 0.665 & 66.5 \\
\hline & & Muscles & 0.714 & 0.510 & 51 \\
\hline & \multirow{3}{*}{ Sediment } & Gills & 0.146 & 0.021 & 2.1 \\
\hline & & Liver & 0.666 & 0.444 & 44.4 \\
\hline & & Muscles & 0.509 & 0.259 & 25.9 \\
\hline \multirow{9}{*}{$\mathrm{Cu}$} & \multirow{3}{*}{ Fish } & Gills & 0.320 & 0.102 & 10.2 \\
\hline & & Liver & 0.820 & 0.673 & 67.3 \\
\hline & & Muscles & 0.320 & 0.102 & 10.2 \\
\hline & \multirow{3}{*}{ Seawater } & Gills & 0.365 & 0.133 & 13.3 \\
\hline & & Liver & 0.642 & 0.412 & 41.2 \\
\hline & & Muscles & 0.920 & 0.846 & 84.6 \\
\hline & \multirow{3}{*}{ Sediment } & Gills & 0.828 & 0.685 & 68.5 \\
\hline & & Liver & 0.759 & 0.577 & 57.7 \\
\hline & & Muscles & 0.632 & 0.400 & 40 \\
\hline
\end{tabular}


first organ to meet pollutants in the form of heavy metals through seawater, because they are stable and have a direct contact with the external environment, while the fish muscles are also in contact with the heavy metals dissolved in sea water (Padrilah et al., 2018; Kamaruzzam et al., 2008). The accumulation of heavy metals in the muscles can increase because the body of the mudskipper fish is submerged in sea water, so that $\mathrm{Cu}$ can bind to the fish's skin and can diffuse into the muscles of the fish. The research by Yunus et al. (2015) also reported that the high concentration of $\mathrm{Cu}$ in fish muscles was caused by high concentrations of $\mathrm{Cu}$ in seawater due to the contamination from factories near sea waters. Similarly, Jovanovic et al. (2011) state that heavy metals can be absorbed by the epithelial or mucosal surfaces of the fish skin. In addition, to the fact that the heavy metals can be absorbed through the surface of the skin, they can also enter the fish tissue through the process of eating in food chains and food webs. Heavy metals infiltrate into the fish body through the surface of the skin / epidermis, gills and the gastrointestinal tract of fish such as the intestines (Yousafzai et al., 2010; Sauliute and Svecevičius, 2015).

Heavy metals are bound to water bodies and are absorbed through the food chain into the tissues. Meanwhile, fish is part of the aquatic food chain, so that heavy metals accumulate in fish bodies higher than in water and sediment (Chaphekar, 1991; Bakhiet, 2015). Canpolat and Calta (2003) suggest that the same heavy metal concentrations distributed in the same organs and tissues will also change depending on the season. The higher the sea water temperature is, the higher the heavy metal toxicity in an organism will be (Tupan and Uneputty, 2017). The heavy metals that enter through the process of eating can also increase the accumulation of $\mathrm{Cd}$ in the liver. Jarup and Akesson, (2009) explained that the bioaccumulation of $\mathrm{Cd}$ can occur through the food chain and trophic levels. The accumulation of $\mathrm{Cd}$ in the liver through sediment and fish accumulators is also associated with the liver's function as a metabolic organ that functions as an excretion. Akan et al. (2012) also argued that heavy metals accumulate in organs because of their function to support the metabolic processes.

Sediment is also the highest medium for the accumulation of $\mathrm{Cu}$ in the gills of the mudskipper fish, compared to $\mathrm{Pb}$ and $\mathrm{Cd}$. The effective contribution of sediment is $68.5 \%$. Saghali et al. (2014) state that sediment is a medium for the accumulation of heavy metals which have broken down and then immerse in the bottom of the water. The research by Reyahi-Khoram et al. (2016) reports that high concentrations of $\mathrm{Cd}$ accumulate in the liver, because the liver is one of the organs that functions as metabolism. In this research, it was found that the liver has the highest accumulation of $\mathrm{Cd}$ and $\mathrm{Cu}$. This may be due to the function of the liver as a detoxification organ.

However, the highest accumulation of $\mathrm{Cu}$ in the liver is through the fish medium (the effective contribution was $67.3 \%$ higher than that of $\mathrm{Pb}$ and $\mathrm{Cd}$ and the other medium). The results of this research are also in line with those obtained by Huseen and Mohammed (2019) that the highest concentration of $\mathrm{Cu}$ in the liver was found in the Ctenopharyngodon idella fish. This was influenced by the binding of $\mathrm{Cu}$ with the sources of the fish food, which then entered the digestive tract and accumulated in the liver of the fish. Tunçsoy and Erdem (2014) report that the heavy metals that enter through the gills can be transferred to the liver through the circulatory system, heavy metal accumulation in the liver because the liver is one of the metabolic organs. Valavanidis et al. (2006) state that the liver has a high accumulation of heavy metals because heavy metals bind to metallothionein, which is a protein synthesized in the liver due to toxic buildup. Yosef and Ghada (2011) added that metallothionein is a protein that detoxifies the accumulation of heavy metals, which means that this protein functions to protect liver against the damage from heavy metal poisoning. Mohammadi et al. (2012) stated that the accumulation of heavy metals is adjusted to the tissue due to the influence of metabolic requirements, physic-chemical properties and heavy metal detoxification processes in certain tissues. This opinion supports the research findings that the liver is an organ that accumulates less heavy metals, except for the accumulation of $\mathrm{Cu}$ from fish with an effective contribution of $67.3 \%$.

\section{CONCLUSIONS}

The results of this research provide important information about the levels of the $\mathrm{Pb}, \mathrm{Cd}$, and $\mathrm{Cu}$ heavy metals in three mangrove waters, namely Poka, Waai and Rutong. Mudskipper fish exposed to heavy metals has undergone histological changes in the gills, liver and muscles. Consequently, its metabolic processes in all three 
organs were inhibited. On the basis of locations of the mangrove, the accumulation of the $\mathrm{Pb}$ and $\mathrm{Cu}$ in fish was Rutong $>$ Poka $>$ Waai; while the accumulation of Cd was Rutong $>$ Waai $>$ Poka. The results of this research also prove that mudskipper, which lives in the mangrove ecosystem, can accumulate heavy metals, so that it can be used as a bioindicator species for heavy metals in waters.

\section{Acknowledgements}

This research was funded by the Faculty of Teacher Training and Education, Pattimura University, with Contract Number: 701/UN13/SK/2019.

\section{REFERENCES}

1. Abalaka, S. 2015. Heavy metals bioaccumulation and histopathological changes in Auchenoglanis occidentalis fish from Tiga dam, Nigeria. Journal of Environmental Health Science \& Engineering, 13(67), 1-8. https://doi.org/10.1186/s40201-015-0222-y.

2. Abdel-Satar, A.M., Shehata, M. 2000. Heavy metals accumulation and macronutrient contents in the flesh of two edible fish inhabiting the River Nile, Egypt. Journal of Egyptian Academic Society for Environmental Development, 7, 99-117.

3. Ahmed, Q., Bat, L., Ali, Q. 2017. Bioaccumulation of nine heavy metals in some tissues of Anodontostoma chacunda (Hamilton, 1822) in the Arabian Sea coasts of Pakistan. Natural and Engineering Sciences, 2(3), 79-92. https://doi.org/10.28978/ nesciences.349296.

4. Akan, J., Mohmoud, S., Shettima, Y., Ogugbuaja, V. 2012. Bioaccumulation of some heavy metals in fish samples from river Benue in Vinikilang, Adamawa state, Nigeria. American Journal of Analytical Chemistry, 3(11), 727-736. https://doi.org/10.4236/ ajac.2012.311097.

5. Al-Yousuf, M., El-Shahawi, M., Al-Ghais, S. 2000. Trace metals in liver, skin and muscle of Lethrinus lentjan fish species in relation to body length and sex. Science of The Total Environment, 256(2-3), 87-94. https://doi.org/10.1016/S0048-9697(99)00363-0.

6. Almiqrh, Abobakir, A., Hadiyanto. 2018. Determination of Heavy Metals $(\mathrm{Pb}, \mathrm{Zn}, \mathrm{Cd}, \mathrm{Cu})$ of coastal urban area of Semarang Indonesia. E3S Web of Conferences, 73, 1-8. https://doi.org/10.1051/ e3sconf/20187303017.

7. Amaral, A., Alvarado, N., Marigómez, I., Cunha, R., Hylland, K., Soto, M. 2002. Autometallography and metallothionein immunohistochemistry in hepatocytes of turbot (Scophthalmus maximus L.) after exposure to $\mathrm{Cd}$ and further depuration treatment.
Biomarkers, 7(6), 491-500. https://doi.org/10.108 0/1354750021000034843.

8. Amundsen, P., Staldvik, F., Lukin, A., Kashulin, N., Popova, O., Reshetnikov, Y. 1997. Heavy metal contamination in freshwater fish from the border region between Norway and Russia. Science of the Total Environment, 201(3), 211-224. https://doi. org/10.1016/s0048-9697(97)84058-2.

9. Anandkumar, A., Nagarajan, R., Prabakaran, K., Rajaram, R. 2017. Trace metal dynamics and risk assessment in the commercially important marine shrimp species collected from the Miri coast, Sarawak, East Malaysia. Regional Studies in Marine Science, 16, 79-88. https://doi.org/10.1016/j.rsma.2017.08.007.

10. Ansari, A., Trivedi, S., Saggu, S., Rehman, H. 2014. Mudskipper: a biological indicator for environmental monitoring and assessment of coastal waters. Journal of Entomology and Zoology Studies, 2(6), 22-33.

11. Arantes, F., Savassi, L., Santos, H., Gomes, M.V., Bazzoli, N. 2016. Bioaccumulation of mercury, cadmium, zinc, chromium, and lead in muscle, liver, and spleen tissues of a large commercially valuable catfish species from Brazil. Anais Da Academia Brasileira de Ciências, 88(1), 137-147. https://doi. org/10.1590/0001-3765201620140434.

12. Ardeshir, R., Movahedinia, A., Rastgar, S. 2017. Fish liver biomarkers for heavy metal pollution: a review article. American Journal of Toxicology, 2(1), 1-8.

13. Arroyo, V., Flores, K., Ortiz, L., Gómez-Quiroz, L., Gutiérrez-Ruiz, M. 2012. Liver and cadmium toxicity. Journal Drug Metabolism Toxicology, 5, 1-7. https://doi.org/10.4172/2157-7609.S5-001.

14. Bakhiet, H.H. 2015. Determination of heavy metals in fish tissues and water from White Nile Khartoum City-Sudan. Journal of Environment Protection and Sustainable Development, 1(3), 178-181.

15. Bazzi, A. 2014. Heavy metals in seawater, sediments, and marine organisms in the gulf of Chabahar, Oman Sea. Journal of Oceanography and Marine Science, 5(3), 20-29. https://doi.org/10.5897/ JOMS2014.0110.

16. Bhagwant, S., Elahee, K. 2002. Pathologic gill lesions in two edible lagoon fish species, Mulloidichthys flavolineatus and Mugil cephalus, from the Bay of Poudre d'Or, Mauritius. Journal Marine Science, 1(1), 35-42.

17. Bhuvaneshwari, R, Padmanaban, K., Rajendran, R. 2015. Histopathological alterations in muscle, liver and gill tissues of zebra fish Danio rerio due to environmentally relevant concentrations of organochlo rine pesticides (OCPs) and heavy metals. International Journal of Environmental Research, 9(4), 1365-1372. https://doi.org/10.22059/ ijer.2015.1029. 
18. Bhuyan, M., Bakar, M., Akhtar, A., Hossain, M., Ali, M., Islam, M. 2017. Heavy metal contamination in surface water and sediment of the Meghna river, Bangladesh. Environmental Nanotechnology, Monitoring \& Management, 8, 273-279. https://doi. org/10.1016/j.enmm.2017.10.003.

19. Bibak, M., Sattari, M., Agharokh, A., Tahmasebi, S., Namin, J. 2018. Assessing some heavy metals pollutions in sediments of the northern Persian Gulf (Bushehr province). Environmental Health Engineering and Management Journal, 5(3), 175-179. https://doi.org/10.15171/EHEM.2018.24.

20. Bu-Olayan, A., Thomas, B. 2008. Trace metals toxicity and bioaccumulation in mudskipper Periophthalmus waltoni Koumans 1941 (Gobiidae: Perciformes). Turkish Journal of Fisheries and Aquatic Sciences, 8(2), 215-218.

21. Camargo, M., Martinez, C.B. 2007. Histopathology of gills, kidney and liver of a neotropical fish caged in an urban stream Marina. Neotropical Ichthyology, 5(3), 327-336. https://doi.org/10.1590/ S1679-62252007000300013.

22. Canpolat, O., Calta, M. 2003. Heavy metals in some tissue and organs of Capoeta capoeta Umbla (Heckel, 1843) fish species in relation to body size, age, sex and seasons. Fresenius Environmental Bulletin, 12(9), 961-966.

23. Chan, J. 2014. The wonderful colors of the hematoxylin-eosin stain in diagnostic surgical pathology. International Journal of Surgical Pathology, 22(1), 12-32. https://doi.org/10.1177/1066896913517939.

24. Chaphekar, S. 1991. An overview on bioindicators. Journal of Environmental Biology, 12, 163-168.

25. Chiang, J. 2014. Liver Physiology: Metabolism and Detoxification. In McManus, L. M \& Mitchell, R. N. (Eds.), Pathobiology of Human Disease (pp. 1770-1782). Elsevier Ltd. https://doi.org/10.1016/ B978-0-12-386456-7.04202-7.

26. Coban, B., Balkis, N., Aksu, A. 2009. Heavy metal levels in sea water and sediment of Zonguldak, Turkey. Journal Black Sea Mediterranean Environment, 15(1), 23-32.

27. Dabruzzi, T., Wygoda, M., Wright, J., Eme, J., Bennett, W. 2011. Direct evidence of cutaneous resistance to evaporative water loss in amphibious mudskipper (family Gobiidae) and rockskipper (family Blenniidae) fishes from Pulau Hoga, Southeast Sulawesi, Indonesia. Journal of Experimental Marine Biology and Ecology, 406(1), 125-129. https://doi. org/10.1016/j.jembe.2011.05.032.

28. Dane, H., Sisman, T. 2015. Histopathological changes in gill and liver of Capoeta capoeta living in the Karasu River, Erzurum. Environmental Toxicology, 30(8), 904-917. https://doi.org/10.1002/tox.21965.

29. Dange, S., Manoj, K. 2015. Bioaccumulation of heavy metals in sediment, Polychaetes (Annelid) worms, Mud Skipper and Mud Crab at Purna river estuary, Navsari, Gujarat, India. International Journal of Current Microbiology and Applied Sciences, 4(9), 571-575.

30. Drishya, M., Binu, K., Mohan, K., Ambikadevi, A., Aswin, B. 2016. Histopathological changes in the gills of fresh water fish, Catla catla exposed to electroplating effluent. International Journal of Fisheries and Aquatic Studies, 4(5), 13-16.

31. Edokpayi, J., Odiyo, J., Msagati, T.A., Popoola, E. 2015. Removal efficiency of faecal indicator organisms, nutrients and heavy metals from a PeriUrban waste water treatment plant in Thohoyandou, Limpopo Province, South Africa. International Journal of Environmental Research and Public Health, 12(7), 7300-7320. https://doi.org/10.3390/ ijerph120707300.

32. El-Moselhy, K., Othman, A., Abd El-Azem, H., ElMetwally, M.E. 2014. Bioaccumulation of heavy metals in some tissues of fish in the Red Sea Egypt. Egyptian Journal of Basic and Applied Sciences, 1, 97-105. http://dx.doi.org/10.1016/j.ejbas.2014.06.001.

33. Elbay-Poulichet, F., Martin, J., Huang, W., Zhu, J. 1987.DissolvedCdbehaviourinsomeselectedFrench and Chinese estuaries: consequences on Cd supply to the ocean. Marine Chemistry, 22(2-4), 125-136. https://doi.org/10.1016/0304-4203(87)90004-1.

34. Eneji, I.S., Sha'Ato, R., Annune, P. 2011. Bioaccumulation of heavy metals in fish (Tilapia zilli and Clarias gariepinus) organs Nigeria. Pakistan Journal of Analytical \& Environmental Chemistry, 12, 25-31.

35. Evans, D., Piermarini, P., Choe, K. 2005. The multifunctional fish gill: dominant site of gas exchange, osmoregulation, acid-base regulation, and excretion of nitrogenous waste. Physiological Reviews, 85, 97-177. https://doi.org/10.1152/ physrev.00050.2003.

36. Fadaeifard, F., Azizi, S. 2014. Histopathological evaluation of environmental gill disease (EGD) in the cultured rainbow trout, Oncorhynchus mykiss. Pelagia Research Library European Journal of Experimental Biology, 4(2), 390-394.

37. Fatima, M., Usamani, N. 2013. Histopathology and bioaccumulation of heavy metals $(\mathrm{Cr}, \mathrm{Ni}$ and $\mathrm{Pb})$ in fish (Channa striatus and Heteropneustes fossilis) tissue: a study for toxicity and ecological impacts. Pakistan Journal of Biological Sciences, 16(9), 412420. https://doi.org/10.3923/pjbs.2013.412.420.

38. Figueiredo-Fernandes, A., Ferreira-Cardoso, J.V., Garcia-Santos, S., Monteiro, S., Carrola, J., Matos, P., Fontainhas-Fernandes, A. 2007. Histopathological changes in liver and gills epithelium of Nile tilapia, Oreochromis niloticus exposed to waterborne copper. Pesquisa Veterinária Brasileira, 27(3), 103-109. https://doi.org/10.1590/ S0100-736X2007000300004. 
39. Flores-Lopes, F., Thomaz, A. 2011. Histopathologic alterations observed in fish gills as a tool in environmental monitoring. Brazilian Journal of Biology, 71(1), 179-188. https://doi.org/10.1590/ S1519-69842011000100026.

40. Frazier, J. 1979. Bioaccumulation of cadmium in marine organisms. Environmental Health Perspectives, 28, 75-79. https://doi.org/10.2307/3428907.

41. Gaetke, L., Chow-Johnson, H., Chow, C. 2014. Copper: toxicological relevance and mechanisms. Archives of Toxicology, 88(11), 1929-1938. https:// doi.org/10.1007/s00204-014-1355-y.

42. Godt, J., Scheidig, F., Grosse-Siestrup, C., Esche, V., Brandenburg, P. 2006. The toxicity of cadmium and resulting hazards for human health. Journal of Occupational Medicine and Toxicology, 10, 1-22. https://doi.org/10.1186/1745-6673-1-22.

43. Gu, Y.G., Lin, Q. 2016. Trace metals in a sediment core from the largest mariculture base of the eastern Guangdong coast South China: vertical distribution, speciation, and biological risk. Marine Pollution Bulletin, 113(1-2), 520-525. https://doi. org/10.1016/j.marpolbul.2016.08.029.

44. Gu, Y.G., Wang, X.N., Lin, Q., Du, F.Y., Ning, J.J., Wang, L. G., Li, Y.F. 2016. Fuzzy comprehensive assessment of heavy metals and $\mathrm{Pb}$ isotopic signature in surface sediments from a bay under serious anthropogenic influences: Daya Bay China. Ecotoxicology Environmental Safety, 126, 38-44.

45. Gulati, K., Reshi, M.R., Rai, N., Ray, A. 2018. Hepatotoxicity: its mechanisms, experimental evaluation and protective strategies. American Journal of Pharmacology, 1(1), 1-9.

46. Gümgüm, B., Tez, Z., Gülsün, Z. 1994. Heavy metal pollution in water, sediment and fish from the Tigris River in Turkey. Chemosphere, 29(1), 111-116. https://doi.org/10.1016/0045-6535(94)90094-9.

47. Hadi, A., Alwan, S. 2012. Histopathological changes in gills, liver and kidney of fresh water fish, Tilapia zillii, exposed to aluminum. International Journal of Pharmacy \& Life Sciences, 3(11), 2071-2081.

48. Hapsari, L., Riani, E., Winarto, A. 2017. Bioaccumulation of lead $(\mathrm{Pb})$ in muscle, skin, and gills of thread fin bream (Nemipterus sp.) in Banten Bay, Indonesia. AACL Bioflux, 10(1), 123-129.

49. Hasan, M., Khan, M.Z., Khan, M., Aktar, S., Rahman, M., Hossain, F., Hasan, A.S.M. 2016. Heavy metals distribution and contamination in surface water of the Bay of Bengal coast. Cogent Environmental Science, 2(1), 1-12. https://doi.org/10.1080 /23311843.2016.1140001.

50. He, Z., Yang, X., Stoffella, P. 2005. Trace elements in agroecosystems and impacts on the environment. Journal of Trace Elements in Medicine and Biology, 19(2-3), 125-140. https://doi.org/10.1016/j. jtemb.2005.02.010.
51. Huseen, H., Mohammed, A. 2019. Heavy Metals Causing Toxicity in Fishes. IOP Conference Series: Journal of Physics: Conference Series, 1294, 1-9. https://doi.org/10.1088/1742-6596/1294/6/062028.

52. Ishibashi, H., Komori, A., Migita, K., Nakamura, M., Shimoda, S. 2009. Liver architecture, cell function and disease. Seminars in Immunopathology, 31(3), 399-409. https://doi.org/10.1007/ s00281-009-0155-6.

53. Jan, A., Azam, M., Siddiqui, K., Ali, A., Choi, I., Haq, Q.M. 2015. Heavy metals and human health: mechanistic Insight into toxicity and counter defense system of antioxidants. International Journal of Molecular Sciences, 16(2), 29592-29630. https:// doi.org/10.3390/ijms161226183.

54. Jarup, L., Akesson, A. 2009. Current status of cadmium as an environmental health problem. Toxicology and Applied Pharmacology, 238(3), 201-208. https://doi.org/10.1016/j.taap.2009.04.020.

55. Javed, M., Usmani, N. 2011. Accumulation of heavy metals in fishes: a human health concern. International Journal of Evironmental Sciences, 2(2), 671682. https://doi.org/10.1186/s40064-016-2471-3.

56. Jovanovic, B., Mihaljev, E., Maletin, S., Palic, D. 2011. Assessment of heavy metal load in chub liver (Cyprinida: Leuciscuscephalus) from the Nisava river (Serbia). Biologica Nyssana, 2(1), 1-7.

57. Kamaruzzam, B., Ong, M., Jalal, K. C. 2008. Level of copper, zinc and lead in fishes of Mangabang Telipot river, Terengganu, Malaysia. Journal of Biological Sciences, 8(7), 1181-1186. https://doi. org/10.3923/jbs.2008.1181.1186.

58. Kaoud, H., El-Dahshan, A. 2010. Bioaccumulation and histopathological alterations of the heavy metals in Oreochromis niloticus fish. Natural Science, $8(4), 147-156$.

59. Kaur, S., Khera, K., Kondal, J. 2018. Heavy metal induced histopathological alterations in liver, muscle and kidney of freshwater cyprinid, Labeo rohita (Hamilton). Journal of Entomology and Zoology Studies, 6(2), 2137-2144.

60. Khabbazi, M., Harsij, M., Hedayati, S.A., Gerami, M., Ghafari-Farsani, H. 2015. Histopathology of rainbow trout gills after exposure to copper. Iranian Journal of Ichthyology, 1(3), 191-196.

61. Khaled, A. 2004. Heavy metal concentrations in certain tissues of five commercially important fishes from El-Mex Bay, Alexandria Egypt. Egyptian Journal of Aquatic Biology and Fisheries, 8(1), 51-64.

62. Khan, M., Ding, X., Khan, S., Brusseau, M., Khan, A., Nawab, J. 2018. The influence of various organic amendments on the bioavailability and plant uptake of cadmium present in mine-degraded soil. Science of the Total Environment, 636, 810-817. https://doi. org/10.1016/j.scitotenv.2018.04.299. 
63. Krishnamoorthy, P., Nagarajan, K. 2013. Levels of heavy metals intwo rivers of Tamilnadu for predicting pollution loads. Journal of Chemical, Biological and Physical Sciences, 4(1), 834-840.

64. Lee, C.C., Hsu, Y.C., Kao, Y.T., Chen, H.L. 2016. Health risk assessment of the intake of butyltin and phenyltin compounds from fish and seafood in Taiwanese population. Chemosphere, 164, 568-575. https://doi.org/10.1016/j. chemosphere.2016.08.141.

65. Lujic, J., Marinović, Z., Miljanović, B. 2013. Histological analysis of fish gills as an indicator of water pollution in the Tamiš river. Acta Agriculturae Serbica, 18(36), 133-141.

66. Maftuch, M., Sanoesi, E., Farichin, I., Saputra, B., Ramdhani, L., Hidayati, S., Fitriyah, N., Prihanto, A. 2018. Histopathology of gill, muscle, intestine, kidney, and liver on Myxobolus sp. infected koi carp (Cyprinus carpio). Journal of Parasitic Diseases, 42(1), 137-143. https://doi.org/10.1007/ s12639-017-0955-x.

67. Male, Y., Malle, D., Bijang, C., Fransina, E., Seumahu, C., Dolaitery, L., Landu, S., Gaspersz, N. 2017. Analysis of cadmium $(\mathrm{Cd})$ and lead $(\mathrm{Pb})$ metals content on sediment inner part of Ambon Bay. Journal of Chemical Research, 5(1), 22-31. https://doi. org/10.30598//ijcr.2017.5-yus. (in Indonesian).

68. Male, Y., Sunarti, S., Nunumete, N. 2014. Analisys of lead $(\mathrm{Pb})$ and chromium $(\mathrm{Cr})$ content in the roots of seagrass (Enhalus acoroides) in waters of Waai and Tulehu village central Maluku Regency. Journal of Chemical Research, 1(2), 66-71. (in Indonesian).

69. Mbeh, G., Kamga, F., Kengap, A., Atem, W., Mbeng, L. 2019. Quantification of heavy metals (Cd, Pb, Fe, $\mathrm{Mg}, \mathrm{Cu}$, and $\mathrm{Zn}$ ) in seafood (fishes and crabs) and evaluation of health risks to consumers in Limbe Cameroon. Journal of Materials and Environmental Science, 10(10), 948-957.

70. Mitra, V., Metcalf, J. 2009. Metabolic functions of the liver. Anaesthesia and Intensive Care Medicine, 10(7), 334-335. https://doi.org/10.1016/j. mpaic.2009.03.011.

71. Mohammadi, M., Askary, S., Khodadadi, M. 2012. Accumulation variations of selected heavy metals in Barbus xanthopterus in Karoon and Dez rivers of Khuzestan, Iran. Iranian Journal of Fisheries Sciences, 11(2), 372-382.

72. Monsefrad, F., Imanpour, N., Heidary, S. 2012. Concentration of heavy and toxic metals $\mathrm{Cu}, \mathrm{Zn}, \mathrm{Cd}$, $\mathrm{Pb}$ and $\mathrm{Hg}$ in liver and muscles of Rutilus frisii $\mathrm{ku}-$ tum during spawning season with respect to growth parameters. Iranian Journal of Fisheries Sciences, 11(4), 825-839.

73. Mortatti, J., Probst, J.L. 2010. Characteristics of heavy metals and their evaluation in suspended sediments from Piracicaba river basin (São Paulo,
Brazil). Revista Brasileira de Geociências, 40(3), 375-379.

74. Moslen, M., Miebaka, C. 2016. Temporal variation of heavy metal concentrations in Periophthalmus Sp. obtained from Azuabie creek in the upper bonny estuary, Nigeria. Current Studies in Comparative Education, Science and Technology, 3(2), 136-147.

75. Mulligan, C., Yong, R., Gibbs, B. 2001. Remediation technologies for metal contaminated soils and groundwater: an evaluation. Engineering Geology, 60(1-4), 193-207. https://doi.org/10.1016/ S0013-7952(00)00101-0.

76. Mustafa, S., Al-Faragi, J., Salman, N., Al-Rudainy, A. 2017. Histopathological alterations in gills, liver and kidney of common carp, cyprinus carpio exposed to lead acetate. Advances in Animal and Veterinary Sciences, 5(9), 371-376. http://doi. org/10.17582/journal.aavs/2017/5.9.371.376.

77. Naghshbandi, N., Zare, S., Heidari, R., Razzaghzadeh, S. 2007. Concentration of heavy metals in different tissues of Astacus leptodactylus from Aras Dam of Iran. Pakistan Journal of Biological Sciences, 10(21), 3956-3959. https://doi.org/10.3923/ pjbs.2007.3956.3959.

78. Nasr, S., Okbah, M., Kasem, S. 2006. Environmental assessment of heavy metal pollution in bottom sediments of Aden Port, Yemen. International Journal of Oceans and Oceanography, 1(1), 99-109.

79. Okafor, E., Opuene, K. 2007. Preliminary assessment of trace metals and polycyclic aromatic hydrocarbons in the sediments. International Journal of Environmental Science and Technology, 4(2), 233-240.

80. Oliva, M., Vicente-Martorell, J., Galindo-Riaño, M., Perales, J. 2013. Histopathological alterations in Senegal sole, Solea senegalensis from a polluted Huelva estuary (SW, Spain) Perales. Fish Physiology Biochemistry, 39(3), 523-545.

81. Padrilah, S., Sabullah, M., Shukor, M.Y.A., Yasid, N., Shamaan, N., Ahmad, S. 2018. Toxicity effects of fish histopathology on copper accumulation. Pertanika Journal of Tropical Agricultural Science, 41(2), 519-540.

82. Patnaik, B., Howrelia, H., Mathews, T., Selvanayagam, M. 2011. Histopathology of gill, liver, muscle and brain of Cyprinus carpio communis L. exposed to sublethal concentration of lead and cadmium. African Journal of Biotechnology, 10(57), 1221812223. https://doi.org/10.5897/AJB10.1910.

83. Pekey, H. 2006. Heavy metals pollution assessment in sediments of the Izmit bay, Turkey. Environmental Monitoring and Assessment, 123(1-3), 219-231. https://doi.org/10.1007/s10661-006-9192-y.

84. Perugini, M., Visciano, P., Manera, M., Zaccaroni, A., Olivieri, V., Amorena, M. 2014. Heavy metal (As, $\mathrm{Cd}, \mathrm{Hg}, \mathrm{Pb}, \mathrm{Cu}, \mathrm{Zn}, \mathrm{Se}$ ) concentrations in muscle and bone of four commercial fish caught in the 
central Adriatic sea, Italy. Environmental Monitoring and Assessment, 186(4), 2205-2213. https://doi. org/10.1007/s10661-013-3530-7.

85. Polgar, G., Sacchetti, A., Galli, P. 2010. Differentiation and adaptive radiation of amphibious gobies (Gobiidae: Oxudercinae) in semi-terrestrial habitats. Journal of Fish Biology, 77(7), 1645-1664. https://doi.org/10.1111/j.1095-8649.2010.02807.x.

86. Rahmanpour, S., Ashtiyani, S.M., Ghorghani, N. 2016. Biomonitoring of heavy metals using bottom fish and crab as bioindicator species, the Arvand river. Toxicology and Industrial Health, 32(7), 12081214. https://doi.org/10.1177/0748233714554410.

87. Rainbow, P. 2007. Trace metal bioaccumulation: models, metabolic availability and toxicity. Environment International, 33(4), 576-582. https://doi. org/10.1016/j.envint.2006.05.007.

88. Rajeshkumar, S., Li, X. 2018. Bioaccumulation of heavy metals in fish species from the Meiliang Bay, Taihu Lake, China. Toxicology Reports, 5, 288-295. https://doi.org/10.1016/j.toxrep.2018.01.007.

89. Rankin, J., Jensen, F. 1993. Environmental effects on fish gill structure and function. In Fish Ecophysiology (pp. 231-264).

90. Rath, P., Panda, U., Bhatta, D., Sahu, K. 2009. Use of sequential leaching, mineralogy, morphology and multivariate statistical technique for quantifying metal pollution in highly polluted aquatic sedimentsa case study: Brahmani and Nandira Rivers, India. Journal of Hazardous Materials, 163(2-3), 632644. https://doi.org/10.1016/j.jhazmat.2008.07.048.

91. Renieri, E., Alegakis, A., Kiriakakis, M., Vinceti, M., Ozcagli, E., Wilks, M., Tsatsakis, A. 2014. Cd, $\mathrm{Pb}$ and $\mathrm{Hg}$ biomonitoring in fish of the mediterranean region and risk estimations on fish consumption. Toxics, 2(3), 417-442. https://doi.org/10.3390/ toxics 2030417.

92. Reyahi-Khoram, M., Setayesh-Shiri, F., Cheraghi, M. 2016. Study of the heavy metals ( $\mathrm{Cd}$ and $\mathrm{Pb}$ ) content in the tissues of rainbow trouts from Hamedan coldwater fish farms. Iranian Journal of Fisheries Sciences, 15(2), 858-869.

93. Rijal, M., Rosmawati, T., Natsir, N., Amin, M., Rochman, F., Badwi, D., Bahalwan, F. 2014. Bioacumulation heavy metals lead $(\mathrm{Pb})$ and cadmium (Cd) seagrass (Enhalus acroides) in Waai and Galala island Ambon. International Journal of Sciences: Basic and Applied Research, 16(2), 349-356.

94. Rodríguez, J., Ríos, S.E., Botero, C.M., 2015. Content of $\mathrm{Hg}, \mathrm{Cd}, \mathrm{Pb}$ and $\mathrm{As}$ in fish species: A review. Vitae, Revista De La Facultad De Ciencias Farmacéuticas Y Alimentarias, 22(2), 148-159. https:// doi.org/10.17533/udea.vitae.v22n2a09.

95. Rosales-Hoz, L., Cundy, A., Bahena-Manjarrez, J. 2003. Heavy metals in sediment cores from a tropical estuary affected by anthropogenic discharges: coatzacoalcos estuary. Estuarine, Coastal and Shelf Science, 58(1), 117-126. https://doi.org/10.1016/ S0272-7714(03)00066-0.

96. Rumahlatu, D., Huliselan, E., 2016. Monitoring (Hg) pollution at Ambon Bay: the use of Apogon beauforti as bioindicator. ILMU KELAUTAN: Indonesian Journal of Marine Sciences, 21(3), 117-122. DOI: https://doi.org/10.14710/ik.ijms.21.3.117-122.

97. Saghali, M., Baqraf, R., Patimar, R., Hosseini, S., Baniemam, M. 2014. Determination of heavy metal (Cr, $\mathrm{Zn}, \mathrm{Cd}$ and $\mathrm{Pb}$ ) concentrations in water, sediment and benthos of the Gorgan bay (Golestan province, Iran). Iranian Journal of Fisheries Sciences, 13(2), 449-455.

98. Salleh, N.H., Halim, M.A. 2018. Enhancing environmental sustainability over fisheries industry through proactive risk evaluation: A case of Tok Bali fishing port. Journal of Sustainability Science and Management Special Issue, 4, 51-63.

99. Sany, S.B., Salleh, A., Sulaiman, A., Sasekumar, A., Rezayi, M., Tehrani, G. 2012. Heavy metal contamination in water and sediment of the Port Klang coastal area, Selangor, Malaysia. Environmental Earth Science, 69(6), 2013-2025.

100. Sauliute, G., Svecevičius, G. 2015. Heavy metal interactions during accumulation via direct route in fish: A review. Zoology and Ecology, 25(1), 7786. https://doi.org/10.1007/s12665-012-2038-8.

101. Shaari, H., Raven, B., Sultan, K., Mohammad, Y., Yunus, K. 2016. Status of heavy metals concentrations in oysters (Crassostrea sp.) from Setiu Wetlands Terengganu, Malaysia. Sains Malaysiana, 45(3), 417-424.

102. Sia-Su, G., Ramos, G., Sia-Su, M.L. 2013. Bioaccumulation and histopathological alteration of total lead in selected fishes from Manila Bay, Philippines. Saudi Journal of Biological Sciences, 20, 353-355. https://doi.org/10.1016/j.sjbs.2013.03.003.

103. Sirait, H., Barus, T., Wahyuningsih, H. 2013. Analysis of content heavy metals in various fish species in Batang Toru river Aek Pahu Tombak, and Aek Pahu Hutamosu district South Tapanuli. Jurnal Perikananan dan Kelautan, 18(2), 1-14. http:// doi.org/10.31258/jpk.18.2.12-25. (in Indonesian).

104. Şireli, U.T., Göncüoğlu, M., Yildirim, Y., Gücükoğlu, A., Çakmak, Ö. 2006. Assessment of heavy metals (cadmium and lead) in vacuum packaged smoked fish species (Mackerel, Salmo salar and Oncorhynhus mykiss) marketed in Ankara (Turkey). Journal of Fisheries \& Aquatic Sciences, 23(3-4), 353-356.

105. Souisa, G. 2017. Konsentrasi logam berat cadmium dan timbal pada air dan sedimen di Teluk Ambon [Concentration of cadmium and lead heavy metals in water and sediments in Ambon Bay]. Tunas-Tunas Riset Kesehatan, 7(1), 1-7. (in Indonesian). 
106. Stern, B. 2010. Essentiality and toxicity in copper health risk assessment: overview, update and regulatory considerations. Journal of Toxicology and Environmental Health Part A, 73(2), 114-127. https://doi.org/10.1080/15287390903337100.

107. Tanjung, R.H., Hamuna, B., Yonas, M. 2019. Assessing heavy metal contamination in marine sediments around the coastal waters of Mimika Regency, Indonesia. Journal of Ecological Engineering, 20(11), 35-42. https://doi. org/10.12911/22998993/113411.

108. Tchounwou, P., Yedjou, C., Patlolla, A., Sutton, D. 2012. Heavy metals toxicity and the environment. Experientia Supplementum, 101, 133-164. https:// doi.org/10.1007/978-3-7643-8340-4_6.

109. Thakur, J., Mhatre, M. 2015. Bioaccumulation of heavy metals in Tilapia mossambicus fish from industrially polluted Patalganga river, India. International Journal of Advanced Research, 3(2), 486-490.

110. Tjahjono, A., Suwarno, D. 2018. The Spatial distribution of heavy metal lead and cadmium pollution and coliform abundance of waters and surface sediment in Demak. Journal of Ecological Engineering, 19(4), 43-54. https://doi. org/10.12911/22998993/89715.

111. Tunçsoy, M., Erdem, C. 2014. Accumulation of copper, zinc and cadmium in liver, gill and muscle tissues of Oreochromis niloticus exposed to these metals separately and in mixture. Fresenius Environmental Bulletin, 23(5), 1143-1149.

112. Tupan, C., Uneputty, P. 2017. Concentration of heavy metals lead $(\mathrm{Pb})$ and cadmium $(\mathrm{Cd})$ in water, sediment and seagrass Thalassia hemprichii in Ambon island waters. AACL Bioflux, 10(6), 1610-1617.

113. Vaidya, S. 2017. Biomonitoring of zooplankton to assess the quality of water in the nagpokhari of Kathmandu valley. International Journal of Zoology Studies, 2(1), 61-65.

114. Valavanidis, A., Vlahogianni, T., Dassenakis, M., Scoullos, M. 2006. Molecular biomarkers of oxidative stress in aquatic organisms in relation to toxic environmental pollutants. Ecotoxicology and Environmental Safety, 64(2), 178-189. https://doi. org/10.1016/j.ecoenv.2005.03.013.

115. Varol, M., Sen, B. 2012. Assessment of nutrient and heavy metal contamination in surface water and sediments of the upper Tigris river, Turkey. Catena, 92, 1-12. https://doi.org/10.1109/ MWSYM.2011.5973443.
116. Velmurugan, B., Selvanayagam, M., Cengiz, E., Unlu, E. 2009. Histopathological changes in the gill and liver tissues of freshwater fish, Cirrhinus mrigala exposed to dichlorvos. Brazilian Archives of Biology and Technology, 52(2), 1291-1296. https:// doi.org/10.1590/S1516-89132009000500029.

117. WHO. 2008. The global burden of diseases: 2004 update Geneva: World Health Organization. http://www.who.int/healthinfo/global_burden_ disease/G BD_report_2004update_full.pdf

118. Wickramasinghe, W.A.A.D., Mubiana, V., Blust, R. 2017. The effects of heavy metal concentration on bioaccumulation, productivity and pigment content of two species of marine macro algae. Sri Lanka Journal of Aquatic Sciences, 22(1), 1-8. https://doi.org/10.4038/sljas.v22i1.7511.

119. Yilmaz, F. 2009. The comparison of heavy metal concentrations $(\mathrm{Cd}, \mathrm{Cu}, \mathrm{Mn}, \mathrm{Pb}$, and $\mathrm{Zn})$ in tissues of three economically important fish (Anguilla mugilcephalus and Oreochromis niloticus) inhabiting Köycegiz lake-mugla (Turkey). Turkish Journal of Science \& Technology, 4(1), 7-15.

120. Yosef, T., Ghada, M. 2011. Assessment of some heavy metal contents in fresh and salted (Feseakh) mullet fish collected from El-Burullus lake, Egypt. Journal of American Science, 7(10), 137- 144.

121. Yousafzai, A., Douglas, P., Khan, A., Ahmad, I., Siraj, M. 2010. Comparison of heavy metals burden in two freshwater fishes Wallago attu and Labeo dyocheilus with regard to their feeding habits in natural ecosystem. Pakistan Journal of Zoology, 42(5), 537-544.

122. Yu, X., Yan, Y., Wang, W.X. 2010. The distribution and speciation of trace metals in surface sediments from the Pearl River Estuary and the Daya Bay, Southern China. Marine Pollution Bulletin, 60(8), 1364-1371. https://doi.org/10.1016/j. marpolbul.2010.05.012.

123. Yunus, S.M., Hamzah, Z., Wood, A., Ahmad. 2015. Assessment of Heavy metals in seawater and fish tissues at pulau Indah, Selangor, Malaysia. AIP Conference Proceedings, 1659, 1-6. https://doi. org/10.1063/1.4916877.

124. Ziyaadini, M., Yousefiyanpour, Z., Ghasemzadeh, J., Zahedi, M. 2017. Biota-sediment accumulation factor and concentration of heavy metals $(\mathrm{Hg}, \mathrm{Cd}$, $\mathrm{As}, \mathrm{Ni}, \mathrm{Pb}$ and $\mathrm{Cu}$ ) in sediments and tissues of Chiton lamyi (Mollusca: Polyplacophora: Chitonidae) in Chabahar Bay, Iran. Iranian Journal of Fisheries Sciences, 16(4), 1123-1134. 